\title{
Desenvolvimento tecnológico por origem de capital: a experiência brasileira recente*
}

\author{
Graziela Ferrero Zucoloto
}

Instituto de Pesquisa Econômica Aplicada (Ipea)

José Eduardo Cassiolato

Instituto de Economia, Universidade Federal do Rio de Janeiro (UFRJ)

\section{Resumo}

Este trabalho tem por objetivo discutir o processo de internacionalização tecnológica e seus impactos na indústria brasileira, com enfoque nas atividades de $\mathrm{P} \& \mathrm{D}$, comparando a performance de empresas nacionais e de filiais de multinacionais. Inicialmente serão apresentados os principais conceitos e a evolução do debate teórico, incluindo as razôes que estimulam e limitam as empresas a internacionalizarem suas atividades tecnológicas. Esta análise será complementada pelo perfil estatístico das empresas multinacionais norte-americanas, verificando a participação do Brasil na atração de tais investimentos. Mais detalhadamente, serão comparadas as atividades tecnológicas de empresas nacionais e filiais de multinacionais atuantes no Brasil, com ênfase nas atividades de P\&D. Testes estatísticos procuram, por fim, identificar a importância da origem de capital na realização de P\&D no Brasil.

* Agradecemos a Fabiano Pompemayer e Flavia Schimidt pelos comentários, críticas e sugestões, isentando-os de qualquer erro ou omissão remanescente no artigo. Nossos agradecimentos também aos pareceristas anônimos da Revista, que com suas sugestões ajudaram a aprimorar o texto. 
Palavras-Chave | P\&D; Desenvolvimento Tecnológico; Origem de Capital; Empresas Multinacionais; Internacionalização Tecnológica.

Códigos JEL | O30.

Technological development by origin of capital: the recent brazilian experience

\begin{abstract}
This paper discusses the impacts of the technological internationalization process in the Brazilian economy, focusing on R\&D activities, comparing national and subsidiaries R\&D performance. After a literature review, the paper presents the statistical profile of US multinational companies, analyzing if Brazil is attracting these investments. In detail, it compares R\&D activities of national and subsidiaries firms in Brazil; statistical tests identify the importance of origin of capital in Brazilian R\&D performance.
\end{abstract}

KeYwords | Technological Development; Origin of Capital; Multinational Enterprises; Technological Internationalization.

JEL-Codes | O30. 


\section{Introdução}

O investimento direto estrangeiro (IDE) é um importante fenômeno relacionado ao processo de globalização econômica. As empresas multinacionais (EMNs), principais condutoras do IDE mundial, intensificaram sua relevância no cenário internacional nas últimas décadas. Se no início dos anos 1990 havia $37 \mathrm{mil}$ empresas multinacionais, acompanhadas de 175 mil subsidiárias, em 2007 estes valores alcançaram, respectivamente, 79 mil e 790 mil. Atualmente, o comércio internacional entre matriz e filiais representa $60 \%$ do total mundial. As empresas multinacionais também dominam grande parte do $\mathrm{P} \& \mathrm{D}$ privado, além de produzirem e controlarem a maior parte da tecnologia avançada do mundo (UNCTAD, 2008; CEPAL, 2008).

As atividades tecnológicas das empresas multinacionais ainda estão fortemente concentradas na matriz. No caso daquelas norte-americanas, os gastos em pesquisa e desenvolvimento (P\&D) das filiais correspondem a aproximadamente $18,6 \%$ dos realizados pelas matrizes (2008), e grande parte deste montante ainda se direciona às naçôes desenvolvidas. (UNCTAD, 2008; CEPAL, 2008; BEA, 2011). Mas, apesar desta intensiva concentração tecnológica, diversos estudiosos apontam tendência de internacionalização das atividades de P\&D. Alguns autores utilizam o termo internacionalização, em vez de globalização, por constatarem que este processo não ocorre em nível global, ou seja, não beneficia os mais diversos países, mas é fortemente caracterizado como "triadização", dado que grande parte destes investimentos ocorre entre Estados Unidos, Europa Ocidental e Japão. Todavia, apesar de os recursos ainda estarem fortemente concentrados nestas naçóes, nas últimas décadas a participação dos países em desenvolvimento nos investimentos em P\&D de empresas multinacionais apresenta crescimento. Tais países se beneficiariam do desenvolvimento tecnológico promovido pelas filiais e da parceria entre empresas estrangeiras e instituiçóes locais.

Este trabalho tem por objetivo discutir o processo de internacionalização tecnológica e seus impactos na indústria brasileira, com enfoque nas atividades de P\&D de empresas multinacionais, comparando-as com o desempenho de firmas locais. Inicialmente, serão apresentados os principais conceitos e a evolução do debate teórico, incluindo as razóes que estimulam e limitam as empresas a internacionalizarem suas atividades tecnológicas. Esta análise será complementada pelo perfil estatístico das empresas multinacionais norte-americanas, verificando a participação do Brasil na 
atração de tais investimentos. ${ }^{1}$ Mais detalhadamente, serão comparadas as atividades tecnológicas de empresas nacionais e filiais de multinacionais atuantes no Brasil, com ênfase nas atividades de P\&D. Testes estatísticos procuram, por fim, identificar a importância da origem de capital na realização de P\&D no Brasil.

\section{0 papel das empresas multinacionais no desenvolvimento tecnológico}

Os estudos iniciais sobre investimento direto estrangeiro surgiram nos anos 1950. A primeira contribuição importante sobre o tema, utilizando o enfoque da organização industrial, foi dada por Penrose, em 1956. Neste trabalho, a autora apresentou o IDE como uma consequência do processo de crescimento da empresa, por meio da diversificação de produtos e penetração em novos mercados. Empresas bemsucedidas teriam recursos internos, como capacidade gerencial e tecnológica, que lhes permitiriam aproveitar as oportunidades de expansão (GONÇALVES, 2002).

$\mathrm{Na}$ década seguinte, Stephen Hymer buscou aprofundar as razóes pelas quais as empresas se engajam na produção transnacional. A partir da teoria de organização industrial, Hymer sugeriu que uma empresa que desejasse produzir em um país diferente de sua origem precisaria possuir algum tipo de ativo específico capaz de sobrepujar vantagens naturais das empresas locais. Tais ativos específicos são associados a poder de mercado, tamanho e economias de escala, capacitação tecnológica e acesso a fontes mais baratas de financiamento. As empresas se engajariam em operaçóes externas por possuírem vantagens inexistentes nas firmas dos países receptores, como tecnologias mais eficientes, sistemas de distribuição mais eficazes ou patentes de produtos diferenciados. Os custos associados à operação internacional deveriam ser compensados por lucros derivados destas vantagens (GONÇALVES, 2002).

Apesar de explicar como e porque empresas começam a se internacionalizar, a teoria de Hymer não esclarece como evolui sua produção internacional. Esta limitação foi compensada pelo trabalho de Vernon (1966), primeiro teórico a fazer uma relação direta entre comércio internacional e IDE, por meio do conceito de “Ciclo de Vida do Produto”. Em texto clássico, Vernon (1966) introduziu a dimensão locacional no conceito, destacando que, ao longo do tempo e com a expansão do mercado mundial, as grandes empresas iriam estabelecer atividades produtivas no

1 O estudo foca nas empresas norte-americanas pela disponibilidade de dados fornecidas pelo Bureau of Economic Analysis (BEA), que disponibiliza informações de matrizes e filiais destas empresas no mundo. As empresas norteamericanas representam $45 \%$ das multinacionais mundiais (UNCTAD, 2005) 
exterior por perceberem uma oportunidade de reduzir custos (de produção e/ou distribuição) ou pela existência de uma ameaça à sua posição competitiva. Neste trabalho, o autor argumentou que os produtos passam por três fases distintas. Na primeira, os produtos novos têm sua produção localizada em países desenvolvidos, sendo que sua internacionalização se expressa por meio de exportaçóes da empresa inovadora a partir de seu país de origem. Na segunda, os produtos em maturação, padronizados, exigem economias de escala e redução de custos de produção, e a posição da empresa inovadora passa a ser ameaçada em decorrência do surgimento de produtos substitutos e diferenciais de custos estabelecidos por novos entrantes. Com o objetivo de não perder mercado, as empresas tendem a estabelecer estruturas produtivas no exterior, em detrimento das exportaçóes. Na terceira fase do produto, de padronização completa, os custos de produção são a base principal da concorrência, e o país em que foi criado pode se tornar seu importador se concorrentes locais estabelecidos ao redor do mundo produzirem os produtos a preços mais acessíveis (GONÇALVES, 2002).

Assim, Hymer e Vernon já enfatizavam a questão tecnológica como elemento importante no processo de internacionalizaçáo. Vernon, em particular, destacou o caráter eminentemente adaptativo dos esforços tecnológicos locais: a internacionalização da produção exigiria a transferência de algumas atividades de $\mathrm{P} \& \mathrm{D}$ relacionadas à adaptação de produtos e processos.

Posteriormente, Dunning tentou integrar linhas explicativas de diferentes abordagens conceituais - teoria da firma, organização industrial, teoria do comércio internacional e teoria locacional - para criar a sua teoria da produção internacional. $\mathrm{Na}$ visão de Dunning, a empresa multinacional deveria não apenas possuir vantagens específicas, mas estas vantagens deveriam ser tais que a firma optaria em explorá-las por si. Para Dunning, há três tipos de vantagens relacionadas à internacionalização das atividades das empresas:

- $\quad$ vantagens da propriedade - ativos, tangíveis ou intangíveis, que conferem poder de mercado às empresas multinacionais;

- vantagens de internalização - refletem a capacidade da empresa em adicionar valor a seu ativo, internalizando-o, em vez de vendê-lo no mercado;

- vantagens de localização - relacionadas a institucionalidade, políticas governamentais e estruturas de mercado demandadas pelas multinacionais.

O IDE ocorreria quando os benefícios de exploração de tais vantagens em um mercado estrangeiro fossem maiores do que seus custos. 
Dunning também sugeriu a existência de quatro tipos de motivação que levariam uma empresa a se internacionalizar: busca e acesso a mercados, busca de matériasprimas, busca de eficiência e de ativos estratégicos. ${ }^{2}$ Os dois primeiros motivos caracterizaram o processo de internacionalização das empresas norte-americanas a partir do pós-guerra e das congêneres europeias que seguiram as pioneiras. Mais recentemente, o acirramento da concorrência a partir da globalização teria aumentado a importância estratégica das duas últimas motivaçóes para internacionalização. A intensificação do processo de globalização associada à difusão do paradigma da microeletrônica tem levado a um aumento na complexidade das formas de internacionalização da produção.

Em uma detalhada análise deste processo, Reddy (1997) apresentou quatro estágios relacionados à internacionalização das atividades de P\&D. Os anos 1960 representariam o início deste processo, dominado pela necessidade de adaptação de produtos e processos e associado à entrada em mercados estrangeiros, envolvendo essencialmente as indústrias mecânica, elétrica e automobilística. Este processo é intensificado nos anos 1970, com o aumento da participação de empresas multinacionais em mercados externos. Neste período, países receptores teriam intensificado as pressôes a empresas multinacionais por transferências de tecnologia, definindo exigências de conteúdo local e comprometimento com metas de exportação. Galina (2003) observou que já nesta década era possível encontrar unidades de P\&D em países em desenvolvimento, como Índia e Brasil. As dificuldades para supervisionar atividades internacionais, presentes até os anos 1970, foram minimizadas com a introdução de novas tecnologias de informação e comunicação. $\mathrm{O}$ grande salto ocorreu na década de 1980, impulsionado pelo processo de globalizaçáo, aumento da competição internacional, (alguma) convergência das preferências dos consumidores em âmbito mundial e crescente base científica de novas tecnologias. Neste cenário, destacam-se as indústrias de microeletrônica, farmacêutica, biotecnologia e novos materiais.

As novas tecnologias de comunicaçáo e informação, assim como a crescente flexibilidade de tecnologias baseadas em ciência, aprimoraram o processo de internacionalização em P\&D. A partir dos anos 1990, este processo foi especialmente determinado pela crescente demanda por cientistas qualificados: dada a escassez de pesquisadores nos países-sede, especialmente nos campos da eletrônica e biotecnologia, as EMNs fortaleceram a expansão de suas redes estrangeiras de P\&D para ter acesso a

2 Ver também as classificações apresentadas mais recentemente por Gammeltoft (2005), Galina (2003) e Archibuchi e Pietrobelli (2002). 
talentos geograficamente dispersos. A preocupação com a redução de custos de P\&D também aparece como fator relevante nesta década. Para minimizá-los, empresas passam a realizar tais atividades, ao menos em parte, em regióes de baixo custo que adquiriram capacitação em C\&T. Tais capacitaçóes não substituem atividades centrais realizadas na matriz e em grandes centros de pesquisa, mas passam a atuar de forma complementar (REDDY, 1997).

Reddy (2000) argumenta que as atividades de P\&D relacionadas especialmente às novas tecnologias (biotecnologia, microeletrônica, farmacêutica, química e software) são mais facilmente internacionalizadas do que em setores convencionais. Nestas, as atividades de P\&D podem se dividir em diferentes módulos, possíveis de serem realizados em lugares diferentes. Tal possibilidade facilita a divisão entre atividades de P\&D centrais (core) e periféricas (no core). Estas últimas passaram a se direcionar para as filiais de naçóes em desenvolvimento, onde podem ser realizadas a custos menores, enquanto os investimentos centrais continuaram concentrados nos paísessede. Para Reddy (1997), em indústrias ligadas a novas tecnologias, os processos de P\&D podem estar geograficamente afastados da produção manufatureira, postura não observada em indústrias tradicionais. ${ }^{3}$

\subsection{Internacionalização de atividades tecnológicas: o debate recente}

A internacionalização de vendas e produção, por meio do investimento direto, é um fenômeno já consolidado. Todavia, no caso das atividades tecnológicas, especialmente $\mathrm{P} \& \mathrm{D}$, este movimento de internacionalização, impulsionado pelas empresas multinacionais, tem se destacado mais recentemente. Diversas análises sugerem que as empresas multinacionais estão internacionalizando suas atividades inovativas, direcionando-as inclusive para países em desenvolvimento. Com base nesta tendência, a literatura vem se debruçando sobre as razóes que levariam as empresas a internacionalizarem tais atividades, em contraposição às razóes para mantê-las centralizadas.

Fatores presentes nos países receptores influenciariam sua capacidade de receber tais investimentos. Alguns fatores locais estão associados à capacidade de atração de P\&D estrangeiro, como ambiente institucional estável, políticas industrial, comercial e de investimentos transparentes, infraestrutura de qualidade, especialmente relacionada a sistemas de comunicação e informação, instituições de pesquisa reconhecidas

3 Sobre esta temática, ver Patel (1996); Patel e Pavitt (1998); Archibuchi e Pietrobelli (2002); Von Zedtwitz e Gassmann (2002), Galina (2003), Gammeltoft (2005) e Minin (2005). 
e presença de cientistas e engenheiros qualificados. A exigência de realização de atividades de $\mathrm{P} \& \mathrm{D}$ também tem sido usada por vários países para maximizar os benefícios originários do IDE, especialmente como contrapartida ao recebimento de incentivos públicos (UNCTAD, 2004).

Entretanto, diversos trabalhos sugerem que grande parte dos investimentos em P\&D ainda é realizada pela matriz. Esta tendência, histórica, relaciona-se ao fato de as empresas multinacionais tradicionalmente manterem o desenvolvimento tecnológico próximo ao núcleo de elaboração estratégica da empresa. Tradicionalmente, P\&D caracteriza-se como uma atividade tácita, arriscada e não padronizada e, portanto, difícil de ser localizada longe da administração central das empresas. Segundo Cassiolato e Lastres (2005), as limitaçóes da internacionalização tecnológica estão associadas à natureza estratégica e complexa dos sistemas de inovação e ao consequente enraizamento das empresas multinacionais - especialmente atividades de P\&D - em seu próprio ambiente local. Deste modo, diversos estudos empíricos argumentam, ainda consistentes com a visão de Vernon (1966), que os gastos em $\mathrm{P} \& D$ por subsidiárias resultam no máximo em adaptação de tecnologias e não em novos desenvolvimentos, dado que o papel principal destas empresas seria somente preservar seu mercado nos países em que atuam, sendo que, para tanto, pouco P\&D precisaria ser realizado (BAS; SIERRA, 2002).

Apesar das facilidades promovidas pelo advento das tecnologias de informaçáa, que facilitam a comunicação entre diferentes localidades geográficas, a realização de P\&D fora da sede pode implicar altos custos de execuçáo, baixa eficácia dos projetos, risco elevado e dificuldades de comunicaçáo com as unidades da matriz acarretadas pela distância (VON ZEDTWITZ; GASSMANN, 2002). Questôes relativas a controle, coordenação, eficiência na comunicação e segurança, necessárias às atividades de $\mathrm{P} \& \mathrm{D}$, assim como às economias de escala envolvidas no processo, estariam associadas à centralização destas atividades. Por um lado, forças centrífugas dispersariam as atividades de P\&D entre regióes periféricas, por outro, forças centrípetas a concentrariam em uma locação central. ${ }^{4}$

Debate mais recente buscou identificar se as empresas internacionalizam P\&D para tirar proveito das capacitaçóes desenvolvidas em sua sede ou para complementálas. No primeiro caso, investimentos são realizados para capitalizar as vantagens

4 Cabe ainda ressaltar que em alguns casos a internacionalização de P\&D não foi resultado da estratégia deliberada da empresa, mas sim consequência da aquisição de empresas estrangeiras que possuíam departamentos de P\&D. Gammeltoft (2005) ressaltou este fato no movimento de fusões e aquisições dos anos 1990, em que grande parte dos estabelecimentos de P\&D estrangeiros foi adquirida incidentalmente. 
existentes na matriz, referentes à adaptação local de produtos e processos e à criação de produtos periféricos; no segundo, os investimentos têm por intuito adicionar novos conhecimentos e habilidades às empresas, por meio da criaçáo de produtos e processos relevantes.

A partir de dados da European Patent Office (EPO), incluindo as maiores multinacionais dos EUA, Japão e Europa para os períodos 1988-1990 e 19941996, Bas e Sierra (2002) concluíram que, na internacionalização tecnológica, duas estratégias tendem a ser seguidas pelas empresas. $\mathrm{Na}$ estratégia mais usual, elas tendem a se internacionalizar tecnologicamente nas áreas/setores em que possuem uma vantagem tecnológica relativa no país-sede e nas quais, simultaneamente, o país receptor possua uma vantagem similar. Neste caso, o objetivo das empresas seria complementar as vantagens competitivas que já possuem, elevando seu estoque de conhecimento e capturando as externalidades geradas por instituiçóes e empresas locais. Na outra estratégia, menos comum, as empresas também tenderiam a explorar no exterior as capacitaçóes que já possuem, mas que não existem de forma relevante no país receptor.

Considerando estas duas estratégias, de modo geral, a primeira tende a ser seguida quando as empresas internacionalizam suas atividades tecnológicas para outros países desenvolvidos; já no caso de se direcionarem para nações em desenvolvimento, o mais comum é atuarem em segmentos setoriais mais dinâmicos, nos quais as instituições destes países não são consideradas competitivas, realizando prioritariamente adaptação de produtos gerados nos países centrais. Patel (1996) observou que as subsidiárias tendem a ser tecnologicamente mais ativas em áreas nas quais os países hospedeiros são relativamente frágeis, ou seja, não existe coincidência entre os setores nos quais o país hospedeiro possui vantagem tecnológica e a presença significativa de empresas estrangeiras nos mesmos.

Para Amsden (2006), as empresas multinacionais tendem a manter seus principais engenheiros e administradores na matriz para desenvolver produtos e processos náo rotineiros, incluindo atividades inovativas. Atividades de alto valor agregado, como $\mathrm{P} \& \mathrm{D}$, são mantidas em casa e, quando internacionalizadas, concentram-se em processos de menor sofisticação. Para a autora, isto vale também para as experiências da China e Índia, apesar das instalaçóes científicas e tecnológicas públicas disponibilizadas nestes países. Amsden (2006) ainda ressaltou que o conteúdo local tende a ser mais elevado em empresas nacionais. As firmas estrangeiras tendem a importar componentes com significativas economias de escala, enquanto as nacionais tendem a estabelecer localmente cadeias de valor. 
Em suma, a análise das estatísticas sobre internacionalização de $P \& D$, a despeito de sua relevância, não é suficiente para entender de fato quais atividades estão sendo direcionadas para países em desenvolvimento. Além disso, o processo de internacionalização tecnológica somente pode gerar impactos positivos aos países receptores, especialmente aqueles em desenvolvimento, se suas instituiçóes tiverem capacitaçōes próprias suficientes para absorver tecnologias externas. Os benefícios da atração de P\&D não são automáticos: podem ser limitados se as subsidiárias criarem pouca ou nenhuma relação com os atores domésticos.

\section{2. Transbordamentos tecnológicos de subsidiárias para empresas domésticas}

Além de analisar a internacionalização das atividades de $\mathrm{P} \& \mathrm{D}$, pesquisadores têm se debruçado sobre os impactos destas atividades nas empresas domésticas, buscando identificar se há transbordamentos positivos ou efeitos crowding out, que limitariam a performance produtiva e tecnológica das firmas domésticas. Os transbordamentos de IDE surgem quando recursos, em especial o conhecimento, são disseminados sem necessariamente a presença de uma relação contratual formal entre os agentes envolvidos. Os transbordamentos tecnológicos ocorrem quando as empresas locais obtêm benefícios a partir da relação com as subsidiárias, que, ao não serem capazes de se apropriar integralmente dos valores gerados, acabam repassando-os parcialmente, e não intencionalmente, às empresas domésticas. Os transbordamentos gerados a partir de subsidiárias podem ocorrer por meio dos seguintes canais:

- efeito demonstração/imitaçáo - aprendizado proporcionado pelas subsidiárias às empresas domésticas, que depende não somente da presença de firmas estrangeiras, mas também da capacidade das empresas domésticas em absorvê-las;

- efeito competição - a competição com subsidiárias estrangeiras impulsiona as empresas domésticas a atualizarem suas tecnologias; ${ }^{5}$

- efeito de treinamento - empresas domésticas absorvem mão de obra treinada nas subsidiárias.

5 Dada a proximidade entre os efeitos demonstração e competição, alguns estudos tentam analisá-los conjuntamente. 
Os efeitos de transbordamento nem sempre são positivos - podem ser nulos, ou até negativos (KONINGS, 2001; AITKEN; HARRISON, 1991; BLOMSTRÖM; KOKKO, 1996; ARAÚJO, 2005). Amsden (2001) apresentou coeficientes de correlaçáo negativos entre a participaçáo das empresas estrangeiras na formaçáo de capital e estoque de investimentos em ciência e tecnologia (C\&T), em países em desenvolvimento, nos anos 1990, considerando diversos tipos de investimento em C\&T, como P\&D $(-0,45)$, patentes $(-0,45)$, publicaçóes científicas $(-0,42)$ ou cientistas e engenheiros envolvidos em $\mathrm{P} \& \mathrm{D}(-0,22)$. Portanto, haveria uma correlação positiva entre investimento estrangeiro relativamente limitado e investimento em capacitaçóes próprias. Na mesma linha, Zucoloto e Toneto Jr. (2005) analisaram os setores manufatureiros no Brasil e mostraram que, quanto maior a participação do capital estrangeiro em uma indústria, menor o esforço tecnológico relativo ${ }^{6}$ por ela realizado.

Mais especificamente, os estudos avaliam os transbordamentos de IDE por meio de relaçóes verticais (interindustriais) ou horizontais (intraindustriais).

Transbordamentos horizontais, ou intraindustriais, refletem as relaçóes entre a empresa e seus concorrentes. Rojec (2007) sintetizou os principais resultados da literatura de transbordamentos de IDE, concluindo que estudos de caso e cross-section setoriais apresentam resultados sistematicamente mais positivos entre transbordamentos IDE e produtividade do que trabalhos em painel no nível da empresa. Os resultados encontrados no nível da empresa, que indicam transbordamentos nulos ou negativos do IDE, podem estar relacionados à capacidade efetiva das empresas multinacionais em protegerem suas vantagens tecnológicas, evitando transbordamentos potenciais.

Já os transbordamentos verticais refletem as relaçôes da empresa com fornecedores e clientes. A dificuldade em se obterem evidências empíricas de transbordamentos verticais está nas limitaçôes de dados sobre as relações insumo-produto em nível industrial. Entre os estudos realizados, destacam-se Smarzynska (2002) e Blalock e Gertler (2003), que encontraram evidências de transbordamento em indústrias verticalmente relacionadas, mas efeitos não significativos de transbordamentos horizontais. Algumas características dos países receptores parecem influenciar tais evidências, como tamanho do mercado, regulação de conteúdo local e capacitaçóes tecnológicas das empresas locais.

6 Distância entre P\&D / valor da produção do Brasil em relação a P\&D / valor da produção média dos países da OCDE. 


\section{0 Brasil no cenário mundial: a experiência das empresas multinacionais norte-americanas}

O processo de internacionalização tecnológica pode ser observado com base nas informaçôes disponibilizadas pelo US Bureau of Economic Analysis (BEA), que concentra estatísticas sobre as empresas norte-americanas, incluindo matrizes e suas filiais. Esta base de dados pode ser considerada um bom indicador da performance tecnológica mundial das empresas multinacionais, pois as subsidiárias norte-americanas representam aproximadamente $42 \%$ do total mundial ${ }^{7}$ (UNCTAD, 2005). Ressalva-se que, pelo contexto histórico e proximidade geográfica, estas empresas tenderam a atuar mais intensamente na América Latina, enquanto as firmas japonesas internacionalizaram-se mais fortemente em direção à Ásia. A análise a seguir refere-se ao período 1989-2008.

O Gráfico 1 apresenta a proporção entre filiais e matrizes para as seguintes variáveis: gastos em $\mathrm{P} \& \mathrm{D}$, vendas, remuneração dos trabalhadores ${ }^{8}$ e número de empregados. Primeiramente, verifica-se que a atividade de P\&D é a menos internacionalizada entre todas as variáveis analisadas. Durante o período observado, a participação das filiais nestas atividades oscilou entre $13 \%$ e 16\%, alcançando um pico de 18,6\% em 2008. Por outro lado, observa-se uma clara tendência de aumento na participação de trabalhadores empregados nas filiais, em relaçáo às matrizes, de 34,2\% em 2001 para 48,0\% em 2008. O mesmo movimento é constatado em relação às vendas, cuja participação das filiais em relação às matrizes passa de 37,1\% para 59,6\%,no mesmo período. Portanto, tais dados sugerem uma crescente importância do emprego e dos mercados locais das subsidiárias de empresas norte-americanas, mas uma relevância significativamente menor em relação à sua participação em atividades tecnológicas, como P\&D. Em outras palavras, a tendência à globalização de P\&D ainda é, de modo significativo, mais modesta do que a globalização de emprego e vendas.

Esta tendência é confirmada quando se observa a relação entre gastos em P\&D e vendas das matrizes e subsidiárias de empresas norte-americanas (Gráfico 2). Notase que esta relação não apresentou mudanças significativas no período observado, mantendo-se próxima a 2,0\%, no caso das matrizes, e oscilando entre $0,74 \%$ e $0,86 \%$, com tendência de queda a partir de 2002, para as filiais. Este movimento recente é determinado por uma crescente participação das vendas de empresas subsidiárias, não acompanhada no mesmo montante pelas atividades de P\&D. Em valores absolutos, houve crescimento dos gastos em P\&D realizados nas filiais, mas em proporção inferior ao das vendas.

7 Considerando as 700 empresas mundiais que mais gastam em P\&D.

8 Incluem-se salários e todos os custos adicionais envolvidos na remuneração do trabalhador. 
GRÁFICO 1

Participação das filiais em $P \& D$, vendas, emprego e remuneração em relação às matrizes de empresas norte-americanas 1992-2008

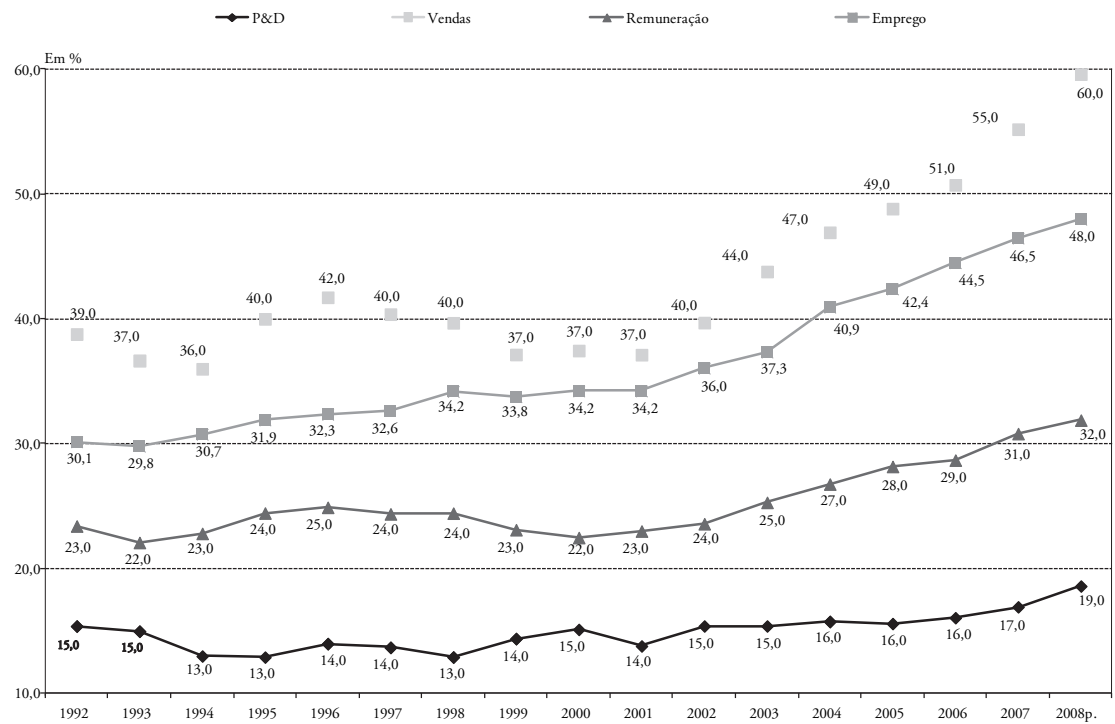

Fonte: US Bureau of Economic Analysis - BEA. Elaboração dos autores.

\section{GRÁFICO 2}

Relação entre gastos em $P \& D$ e vendas nas matrizes

e filiais de empresas norte-americanas

1990-2008

$\sim$ Matrizes norte-americanas $\quad-$ Filiais norte-americanas

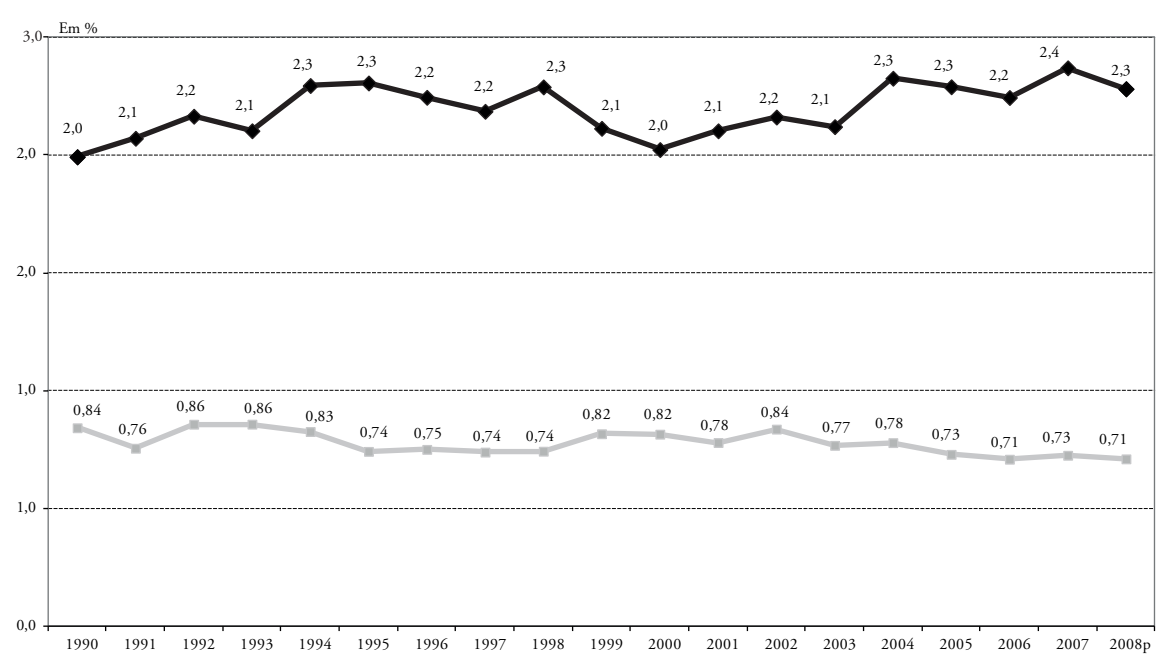

Fonte: US Bureau of Economic Analysis - BEA. Elaboração dos autores. 
Entretanto, entre as filiais, é possível observar uma realocação dos gastos entre os países receptores de investimentos das empresas norte-americanas, sendo que, entre aqueles pertencentes ao agrupamento BRICS, China e Índia vêm ganhando significativo espaço, onde a relação $\mathrm{P} \& \mathrm{D} /$ vendas alcança patamares similares aos observados em filiais de países desenvolvidos. Já as subsidiárias atuantes no Brasil não apresentaram dinamismo similar, revelando esforço tecnológico módico se comparado às naçóes citadas (Tabela 1).

TABELA 1

Relação entre gastos em P\&D e vendas das filiais de empresas norte-americanas Países pertencentes ao agrupamento BRICS - 1989-2007

\begin{tabular}{lc|c|c|c|c|c|c|c|c|c|cc}
\hline \multicolumn{1}{c}{ Países } & $\mathbf{1 9 8 9}$ & $\mathbf{1 9 9 1}$ & $\mathbf{1 9 9 4}$ & $\mathbf{1 9 9 7}$ & $\mathbf{2 0 0 0}$ & $\mathbf{2 0 0 1}$ & $\mathbf{2 0 0 2}$ & $\mathbf{2 0 0 3}$ & $\mathbf{2 0 0 4}$ & $\mathbf{2 0 0 5}$ & $\mathbf{2 0 0 6}$ & $\mathbf{2 0 0 7}$ \\
\hline Total & $\mathbf{0 , 6 9}$ & $\mathbf{0 , 7 6}$ & $\mathbf{0 , 8 3}$ & $\mathbf{0 , 7 4}$ & $\mathbf{0 , 8 2}$ & $\mathbf{0 , 7 8}$ & $\mathbf{0 , 8 4}$ & $\mathbf{0 , 7 7}$ & $\mathbf{0 , 7 8}$ & $\mathbf{0 , 7 3}$ & $\mathbf{0 , 7 1}$ & $\mathbf{0 , 7 4}$ \\
Brasil & 0,29 & 0,55 & 0,72 & 0,75 & 0,40 & 0,33 & 0,52 & 0,50 & 0,50 & 0,43 & 0,54 & 0,50 \\
Rússia & - & - & 0,00 & 0,00 & 0,03 & - & 0,03 & 0,01 & 0,16 & 0,20 & 0,44 & 0,36 \\
Índia & 0,62 & 0,98 & 0,51 & 0,84 & - & - & 0,88 & 0,81 & 0,86 & 1,90 & 1,63 & 1,60 \\
China & - & 0,10 & 0,22 & 0,29 & 1,92 & - & 1,56 & 1,16 & 0,93 & 0,86 & 0,79 & 0,97 \\
África do Sul & 0,34 & 0,39 & 0,39 & 0,34 & 0,19 & 0,24 & - & 0,18 & 0,14 & 0,16 & 0,25 & 0,25 \\
\hline
\end{tabular}

Fonte: US Bureau of Economic Analysis - BEA.

Apesar do frágil desempenho comparativamente observado no Brasil, as empresas multinacionais, de forma geral, são responsáveis por grande parte do P\&D realizado no país. Em uma análise com 30 países, Arruda, Vermulm e Hollanda (2006) mostram que, no Brasil, esta participaçáo pode ser considerada comparativamente elevada (Gráfico 3).

Em alguns países, a diferença de esforço em $P \& D$ entre subsidiárias e empresas domésticas deve-se à baixa intensidade deste último grupo - caso de Austrália e Irlanda; já países em que as empresas domésticas apresentam elevado esforço em P\&D, o esforço das subsidiárias aparece proporcionalmente menor - França, Alemanha, Países Baixos e Suécia (OCDE, 1998). Para entender melhor este fenômeno no cenário brasileiro, torna-se relevante, portanto, analisar com mais detalhe a atuação tecnológica de empresas multinacionais no país, e sua comparação com firmas domésticas. 


\section{GRÁFICO 3}

Participação de subsidiárias de empresas estrangeiras nas atividades em P\&D Países selecionados - 2003

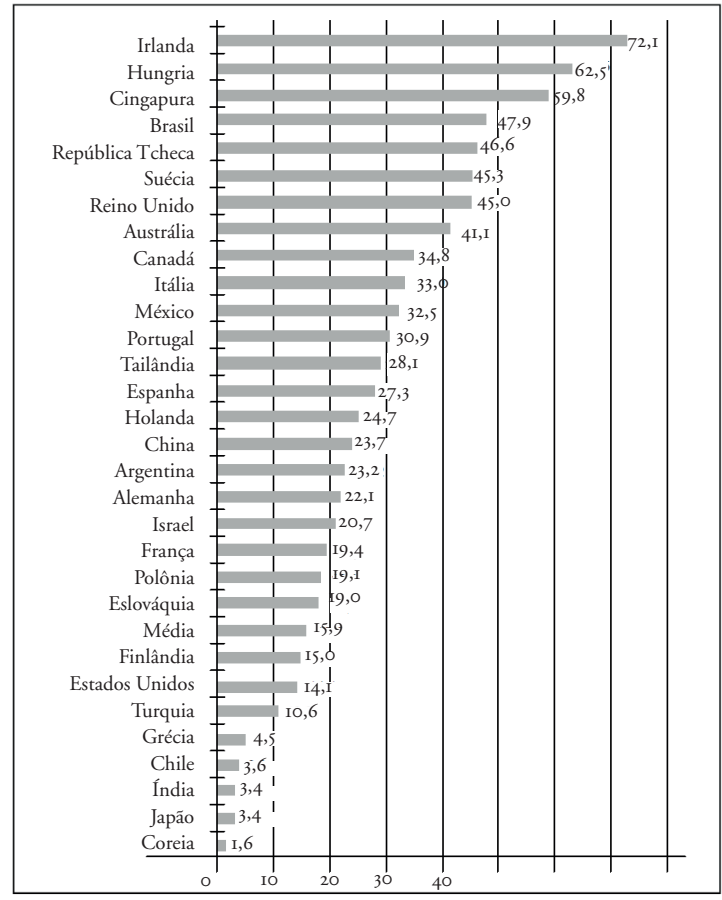

Fonte: Arruda, Vermulm e Hollanda (2006).

\section{Investimento tecnológico no Brasil: uma comparação por origem de capital das empresas do setor industrial ${ }^{9}$}

A análise a seguir é realizada com base em estatísticas da Pintec - Pesquisa de Inovação Tecnológica, produzida pelo IBGE, para os anos 2000, 2003 e 2005, ${ }^{10}$ que fornece informaçóes sobre as atividades de inovação tecnológica das empresas brasileiras.

9 No Brasil, a Lei 4.390/64 definiu o conceito de empresa subsidiária como aquela cuja base de participação do capital pertencesse em pelo menos 50\% à empresa estrangeira. Os investimentos externos diretos (IED) têm registro obrigatório no Banco Central do Brasil determinado pela Lei 4.131, de 03.09.1962, e pela Lei 11.371, de 28.11.2006, regulamentado no Banco Central pela Circular 2.997, de 15.08.2000. Essa Circular define investimento externo direto, no artigo segundo, como "as participações, no capital social de empresas no país, pertencentes a pessoas físicas ou jurídicas residentes, domiciliadas ou com sede no exterior, integralizadas ou adquiridas na forma da legislação em vigor, bem como o capital destacado de empresas estrangeiras autorizadas a operar no país", excluindo, no artigo 10, "das disposições desta Circular as participações societárias de investidores não-residentes adquiridas nos mercados financeiro e de capitais, bem como os rendimentos delas decorrentes, que constituam investimentos em portfólio regidos por normas específicas, passíveis de registro no Bacen por meio de procedimentos e transações próprias do SISBACEN".

10 Este estudo foi realizado antes da divulgação da Pintec 2008, ocorrida no final de 2010. 
A análise descritiva concentra-se em empresas brasileiras de grande porte. ${ }^{11} \mathrm{~A}$ Tabela 2 caracteriza este grupo de firmas por origem de capital. Segundo dados da Pintec, em 2005, havia 1.410 empresas de grande porte no Brasil, sendo 74,8\% nacionais e o restante, subsidiárias. Este percentual sofreu pouca alteração desde 2000, com alguma redução na participação das subsidiárias ao longo do período estudado. Esta queda na participação das subsidiárias é observada também em relação ao pessoal ocupado. O predomínio de empresas nacionais torna-se menos significativo quando é considerado o valor da receita líquida de vendas (RLV): em 2005, sua participação foi de $56 \%$.

As subsidiárias apresentaram, em todos os anos, participação no comércio exterior significativamente mais elevada que as nacionais, no que se refere tanto a exportaçóes quanto importaçóes. Se, por um lado, as exportações elevadas são associadas à capacidade competitiva, o considerável montante importado celebra dúvidas relativas ao estabelecimento de parcerias entre estas empresas e fornecedores locais, que poderiam gerar os transbordamentos verticais discutidos anteriormente.

Os dados agregados apresentados na Tabela 2 sugerem que as multinacionais apresentam indicadores de inovação superiores às nacionais em todos os critérios avaliados: percentual de empresas inovadoras; atividades internas de P\&D; aquisição de P\&D e outros conhecimentos externos; aquisição de máquinas e equipamentos; e pessoal ocupado em P\&D. Antes de indicar elevado esforço tecnológico das empresas multinacionais no Brasil, diversos trabalhos ressaltam que este cenário é, antes de tudo, reflexo do limitado investimento em P\&D das empresas nacionais (ARRUDA; VERMULM; HOLLANDA, 2006). As firmas nacionais se destacam apenas por direcionar proporcionalmente mais recursos à realização de $\mathrm{P} \& \mathrm{D}$, quando comparada às demais atividades inovativas (2005).

11 A classificação das empresas por origem de capital seguiu as respostas apresentadas no questionário da Pintec (questão 1: características da empresa). A empresa foi classificada como nacional se respondeu que a origem do capital controlador da empresa era nacional; nos demais casos, quando respondeu que a origem do capital controlador era estrangeira ou mista, a empresa foi classificada como subsidiária de multinacional.

A amostra da Pintec é realizada a partir de um estrato certo, em que todas as empresas são incluídas com probabilidade um, e dois estratos amostrados, diferenciados pelo grau de incerteza com relação à presença do fenômeno em estudo. No estrato certo, são incluídas somente as empresas de grande porte (com 500 ou mais pessoas ocupadas na indústria de transformação). Em cada pesquisa, o estrato amostral foi associado a um fator de expansão, indicando a representatividade da firma entrevistada. A elaboração do fator de expansão leva em conta algumas características da firma, mas não sua origem de capital. Esta limitação distorce a análise das atividades tecnológicas empresariais da indústria brasileira por origem de capital, limitando a utilização do fator de expansão. Portanto, optou-se por concentrar a análise descritiva das atividades tecnológicas por origem de capital nas empresas brasileiras de grande porte. O universo selecionado é representativo: empresas de grande porte são responsáveis por $75 \%$ dos gastos privados em P\&D realizados no país (Pintec, 2005). 
TABELA 2

Empresas de grande porte, por origem do capital, segundo variáveis selecionadas

Brasil - 2000-2003

\begin{tabular}{|c|c|c|c|c|c|c|}
\hline \multirow[b]{2}{*}{ Variáveis } & \multicolumn{2}{|c|}{2000} & \multicolumn{2}{|c|}{2003} & \multicolumn{2}{|c|}{2005} \\
\hline & Nacionais & $\begin{array}{l}\text { Multina- } \\
\text { cionais }\end{array}$ & Nacionais & $\begin{array}{l}\text { Multina- } \\
\text { cionais }\end{array}$ & Nacionais & $\begin{array}{l}\text { Multina- } \\
\text { cionais }\end{array}$ \\
\hline $\begin{array}{l}\text { Participação } \\
\text { no número de } \\
\text { empresas (\%) }\end{array}$ & 72,4 & 27,6 & 72,5 & 27,5 & 74,8 & 25,2 \\
\hline $\begin{array}{l}\text { Participação no } \\
\text { pessoal ocupado } \\
\text { - PO (\%) }\end{array}$ & 67,1 & 32,9 & 68,4 & 31,6 & 71,2 & 28,8 \\
\hline $\begin{array}{l}\text { Participação em } \\
\text { RLV (\%) }\end{array}$ & 52,9 & 47,1 & 56,7 & 43,3 & 56,0 & 44,0 \\
\hline $\begin{array}{l}\text { Exportações / } \\
\text { empresa (US\$) }\end{array}$ & 19.069 .317 & 45.867 .289 & 25.124 .509 & 66.411 .394 & 38.157 .017 & 103.174 .521 \\
\hline $\begin{array}{l}\text { Importações / } \\
\text { empresa (US\$) }\end{array}$ & 17.347 .052 & 40.812 .058 & 13.628 .571 & 35.940 .832 & 20.020 .575 & 64.070 .828 \\
\hline $\begin{array}{l}\text { Firmas inovadoras } \\
\text { / total (\%) }\end{array}$ & 71,06 & 87,03 & 69,57 & 82,60 & 75,71 & 88,20 \\
\hline $\begin{array}{l}\text { P\&D / vendas } \\
(\%)\end{array}$ & 0,75 & 0,95 & 0,58 & 0,85 & 0,63 & 0,71 \\
\hline $\begin{array}{l}\text { P\&D / demais } \\
\text { atividades } \\
\text { inovativas (\%) }\end{array}$ & 26,36 & 27,51 & 35,20 & 32,01 & 39,07 & 32,82 \\
\hline $\begin{array}{l}\mathrm{PO} \text { em } \mathrm{P} \& \mathrm{D} / \mathrm{PO} \\
(\%)\end{array}$ & 0,47 & 0,98 & 0,51 & 1,16 & 0,37 & 1,08 \\
\hline $\begin{array}{l}\text { Aquisição de } \\
\text { P\&D e outros } \\
\text { conhecimentos } \\
\text { externos / vendas } \\
\text { (\%) }\end{array}$ & 0,19 & 0,60 & 0,19 & 0,60 & 0,11 & 0,27 \\
\hline $\begin{array}{l}\text { Aquisição de } \\
\text { máquinas e } \\
\text { equipamentos / } \\
\text { vendas (\%) }\end{array}$ & 1,83 & 1,83 & 0,87 & 1,55 & 0,82 & 1,14 \\
\hline
\end{tabular}

Fonte: IBGE. Pesquisa de Inovação Tecnológica - Pintec; Secretaria de Comércio Exterior - Secex. Elaboração dos autores. Nota: Valores excluem informaçốes das empresas nacionais do setor de fumo e multinacionais das indústrias de confecçốes, couro e calçados e petróleo e álcool, por respeito ao sigilo de informaçōes exigido pelo IBGE - não identificação das empresas envolvidas.

A Tabela 3 apresenta as relaçóes de cooperação estabelecidas pelas empresas de grande porte brasileiras. Entre aquelas que cooperam, destaca-se a participação significativa de fornecedores e clientes/consumidores, em detrimento da relação com concorrentes. Este indicador está na mesma linha das principais conclusóes obtidas por estudos sobre externalidades tecnológicas, os quais sugerem que, em diversos países e indústrias analisadas, transbordamentos verticais, fruto das relaçóes de empresas 
com fornecedores e clientes, são mais significativos do que os horizontais, entre concorrentes. No caso das subsidiárias, também sobressai a cooperação com "outras empresas do grupo": considerando-se que filiais de multinacionais, especialmente de países em desenvolvimento, atuam na adaptação de produtos e processos ao mercado local, respondem por parcela da geração de produtos desenvolvidos ao longo do globo e/ou utilizam grande parte de tecnologias geradas no exterior, a cooperação com a matriz torna-se, em todos os casos, de extrema relevância.

TABELA 3

Empresas de grande porte que possuem relações de cooperação, por origem do capital, segundo tipos de cooperação

Brasil - 2000-2005

\begin{tabular}{|c|c|c|c|c|c|c|}
\hline \multirow{2}{*}{ Tipos de cooperação } & \multicolumn{2}{|c|}{2000} & \multicolumn{2}{|c|}{2003} & \multicolumn{2}{|c|}{2005} \\
\hline & Nacionais & $\begin{array}{l}\text { Multina- } \\
\text { cionais }\end{array}$ & Nacionais & $\begin{array}{l}\text { Multina- } \\
\text { cionais }\end{array}$ & Nacionais & $\begin{array}{l}\text { Multina- } \\
\text { cionais }\end{array}$ \\
\hline $\begin{array}{l}\text { Total de empresas } \\
\text { que cooperaram }\end{array}$ & 25,8 & 39,1 & $x$ & $x$ & $x$ & $x$ \\
\hline $\begin{array}{l}\text { Centros de capacitação } \\
\text { profissional e assistência } \\
\text { técnica }\end{array}$ & 8,9 & 6,4 & 7,9 & 6,3 & 9,5 & 7,0 \\
\hline $\begin{array}{l}\text { Universidades e } \\
\text { institutos de pesquisa }\end{array}$ & 15,8 & 16,0 & 24,5 & 17,2 & 28,2 & 21,1 \\
\hline Empresas de consultoria & 6,4 & 4,8 & 15,3 & 7,5 & 15,4 & 8,6 \\
\hline Concorrentes & 6,4 & 3,2 & 5,6 & 4,0 & 7,0 & 4,9 \\
\hline Fornecedores & 51,5 & 34,4 & 52,3 & 40,2 & 51,6 & 41,1 \\
\hline Clientes / consumidores & 42,6 & 47,2 & 41,7 & 46,0 & 37,0 & 40,5 \\
\hline $\begin{array}{l}\text { Outra empresa do } \\
\text { grupo }\end{array}$ & 8,9 & 66,4 & 16,2 & 58,6 & 10,6 & 62,2 \\
\hline
\end{tabular}

Fonte: IBGE. Pesquisa de Inovação Tecnológica - Pintec; Secretaria de Comércio Exterior - Secex. Elaboração dos autores. Nota: Valores excluem informaçôes das empresas nacionais do setor de fumo e multinacionais das indústrias de confecçōes, couro e calçados e petróleo e álcool, por respeito ao sigilo de informaçôes exigido pelo IBGE - não identificaçăo das empresas envolvidas.

A significativa participação de grandes empresas nos investimentos em $\mathrm{P} \& \mathrm{D}$ é acompanhada por uma concentração similar em termos setoriais (Tabela 4). No caso das subsidiárias, aproximadamente $50 \%$ da RLV se concentra em três setores: indústria automobilística, máquinas e equipamentos e produtos químicos. Entre as nacionais, percentual similar é alcançado pela participação conjunta das indústrias de petróleo e álcool e de alimentos e bebidas. 
Em relação aos investimentos em $\mathrm{P} \& \mathrm{D}$, esta concentração é ainda mais significativa. No caso das subsidiárias, a indústria automobilística representa $53,8 \%$ dos recursos direcionados a esta atividade. O perfil tecnológico deste setor no Brasil tem sido destacado por diversas publicaçóes. A Unctad (2005) sugeriu que a indústria automobilística é uma exceção ao comportamento das subsidiárias atuantes no Brasil, em que P\&D adaptativo é dominante. A publicação enfatizou ainda que poucas indústrias farmacêuticas estrangeiras fazem $P \& D$ no país, apesar da disponibilidade de laboratórios públicos e capacitaçôes locais. Arruda, Vermulm e Hollanda (2006) também destacaram a preponderância da "tropicalização" nas atividades tecnológicas de subsidiárias brasileiras, enfatizando o setor automobilístico como exceção, exemplificado pela atuação da empresa General Motors no país, que compete com outras subsidiárias do grupo pelo direito de projetar e construir novos veículos e realizar atividades ligadas aos principais projetos da empresa. Os autores ainda ressaltaram que este processo de concentração em poucos setores é também observado em outros países: em 2002, três quartos das atividades de P\&D das subsidiárias de multinacionais na Ásia eram relacionados a indústrias de computadores e eletrônicos; na Índia, percentual equivalente estava relacionado com o desenvolvimento de software (ARRUDA, VERMULM; HOLLANDA, 2006).

Em relação às empresas nacionais, petróleo e álcool e outros equipamentos de transporte respondem por $61,6 \%$ dos investimentos em P\&D no país. Estas duas indústrias são exemplos constantemente citados como setores construídos em base estatal, cujos investimentos públicos em tecnologia de ponta foram historicamente essenciais na formação de sistemas setoriais de inovação internacionalmente competitivos. Mesmo após o processo de liberalização econômica vivenciado no país, esta histórica construção de capacitações ainda parece se refletir no aprimoramento tecnológico industrial brasileiro.

O esforço tecnológico em $\mathrm{P} \& \mathrm{D}$, mensurado pela relação $\mathrm{P} \& \mathrm{D} /$ vendas, sugere que, se no agregado as empresas multinacionais apresentaram esforço mais elevado que as nacionais, setorialmente este cenário sofre alteraçóes. Em 2005, entre as 18 indústrias observadas, em 12 o esforço realizado por empresas nacionais foi superior. Além disso, em 64\% das indústrias, as empresas nacionais direcionaram proporcionalmente mais recursos à realização de $\mathrm{P} \& \mathrm{D}$ do que às demais atividades inovativas. 


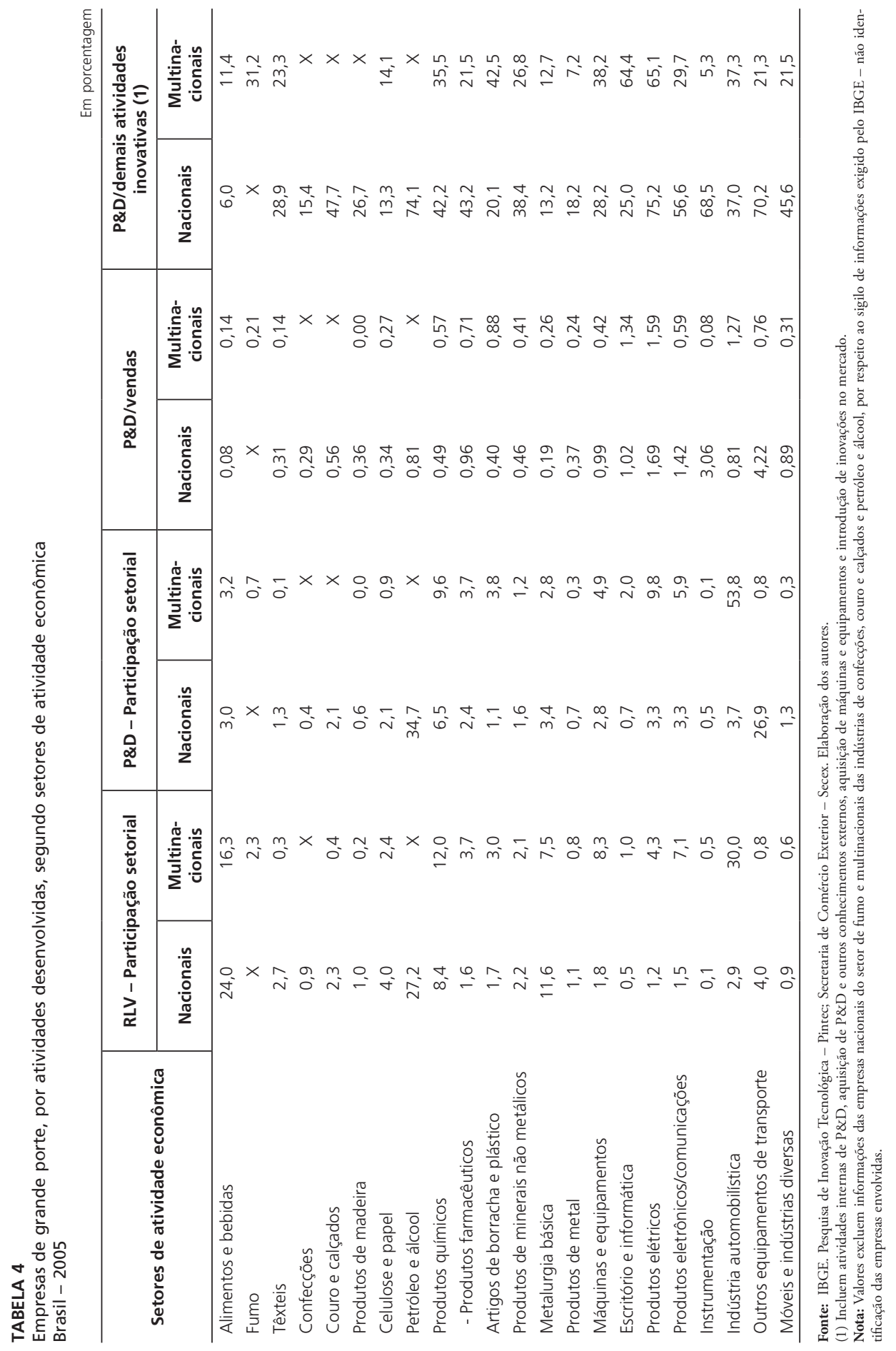




\subsection{As 150 empresas multinacionais selecionadas: comparação entre as filiais brasileiras e o desempenho mundial}

Para complementar a análise descritiva, informaçóes sobre empresas multinacionais obtidas na Pintec 2005 foram associadas a dados disponibilizados pela European Commission 2006, relativos às 2.000 empresas mais inovadoras do mundo. ${ }^{12}$ Neste processo, foram encontradas 150 empresas multinacionais com filiais acima de 500 empregados no Brasil, respondendo por 70\% dos gastos em P\&D de empresas multinacionais de grande porte no país, sendo, portanto, representativas do esforço inovativo das subsidiárias brasileiras. A análise se concentra nas informaçóes sobre P\&D, vendas e número de empregados das 150 empresas selecionadas, classificadas de acordo com seu setor CNAE. Sua importância está em permitir a comparação do desempenho destas firmas no Brasil e no mundo.

A Tabela 5 revela que a receita líquida de vendas por empregado das filiais brasileiras é relativamente próxima ao padrão mundial, em alguns casos superando-o. Já os gastos em P\&D por empregado das filiais brasileiras estão muito aquém. Enquanto a receita média por empregado das filiais brasileiras representa 76,1\% da receita média destas empresas no mundo, no caso da $\mathrm{P} \& \mathrm{D}$ esta proporção se reduz para $10,4 \% .^{13}$

Complementarmente, a Tabela 6 sugere que o esforço tecnológico das filiais analisadas representa somente $13,6 \%$ do realizado por estas empresas em nível mundial: enquanto a relação $\mathrm{P} \& \mathrm{D} /$ vendas destas empresas situa-se em torno de 5,6\% no mundo, no Brasil esta proporção cai para 0,8\%. Este percentual é especialmente baixo nas empresas que compóem os setores de saúde - farmacêutico e instrumentação -, nos quais o esforço em P\&D no Brasil atinge, respectivamente, $8,8 \%$ e $1,6 \%$ do realizado no mundo. Mesmo no caso do setor automobilístico, a distância entre os esforços das empresas multinacionais no Brasil (1,3\%) e no mundo $(4,1 \%)$ é significativa. ${ }^{14}$

\footnotetext{
12 Esta publicação inclui 1.000 empresas europeias e 1.000 não europeias. Os dados disponibilizados referem-se à atuação destas empresas no mundo, agregando matriz e filiais. Empresas brasileiras que fazem parte desta lista são Petrobras, Vale do Rio Doce, Embraer, Weg e Brasken.

13 A exceção se concentra no setor de minerais não metálicos, cujo resultado precisa ser mais bem estudado.

14 A exceção novamente se concentra no setor de minerais não metálicos.
} 
TABELA 5

Gastos com P\&D e receita líquida de vendas por empregado das 150 empresas multinacionais mais inovadoras do mundo com filiais brasileiras, segundo setores de atividade econômica 2006

\begin{tabular}{|c|c|c|c|c|c|c|}
\hline \multirow{2}{*}{$\begin{array}{l}\text { Setores de atividade } \\
\text { econômica }\end{array}$} & \multicolumn{2}{|c|}{$\begin{array}{l}\text { P\&D por empregado } \\
\text { (R\$) }\end{array}$} & \multirow{2}{*}{$\begin{array}{l}\text { Filiais } \\
\text { brasi- } \\
\text { leiras/ } \\
\text { mundo } \\
(\%)\end{array}$} & \multicolumn{2}{|c|}{$\begin{array}{c}\text { Receita líquida de vendas } \\
\text { por empregado } \\
\text { (R\$) }\end{array}$} & \multirow{2}{*}{$\begin{array}{c}\text { Filiais } \\
\text { brasi- } \\
\text { leiras/ } \\
\text { mundc } \\
(\%)\end{array}$} \\
\hline & Mundo & $\begin{array}{l}\text { Filiais } \\
\text { brasi- } \\
\text { leiras }\end{array}$ & & Mundo & $\begin{array}{l}\text { Filiais } \\
\text { brasi- } \\
\text { leiras }\end{array}$ & \\
\hline Indústria extrativa & $5.323,0$ & - & - & $463.679,0$ & $364.853,5$ & 78,7 \\
\hline $\begin{array}{l}\text { Fabricação de produtos } \\
\text { alimentícios }\end{array}$ & $11.061,6$ & 915,1 & 8,3 & $542.254,8$ & $339.712,9$ & 62,6 \\
\hline $\begin{array}{l}\text { Fabricação de produtos } \\
\text { do fumo }\end{array}$ & $7.943,0$ & $3.386,3$ & 42,6 & $914.123,5$ & $744.994,9$ & 81,5 \\
\hline $\begin{array}{l}\text { Fabricação de celulose } \\
\text { e papel }\end{array}$ & $6.847,8$ & $2.203,6$ & 32,2 & $733.371,6$ & $701.853,5$ & 95,7 \\
\hline $\begin{array}{l}\text { Fabricação de produtos } \\
\text { químicos }\end{array}$ & $34.252,7$ & $4.308,9$ & 12,6 & $1.041 .441,5$ & $1.016 .990,8$ & 97,7 \\
\hline $\begin{array}{l}\text { - Fabricação de produtos } \\
\text { farmacêuticos }\end{array}$ & $129.177,8$ & $7.259,4$ & 5,6 & $855.089,6$ & $544.854,2$ & 63,7 \\
\hline $\begin{array}{l}\text { Fabricação de artigos } \\
\text { de borracha e plástico }\end{array}$ & $6.281,7$ & $1.573,4$ & 25,0 & $436.838,8$ & $284.446,8$ & 65,1 \\
\hline $\begin{array}{l}\text { Fabricação de produtos } \\
\text { de minerais não metálicos }\end{array}$ & $3.362,2$ & $2.851,8$ & 84,8 & $500.490,3$ & $512.070,7$ & 102,3 \\
\hline $\begin{array}{l}\text { Metalurgia básica (metais } \\
\text { ferrosos) }\end{array}$ & $13.066,6$ & $3.532,4$ & 27,0 & $520.708,8$ & $475.889,6$ & 91,4 \\
\hline $\begin{array}{l}\text { Metalurgia de metais não- } \\
\text { ferrosos }\end{array}$ & $10.058,7$ & 144,9 & 1,4 & $1.344 .845,6$ & $799.114,9$ & 59,4 \\
\hline $\begin{array}{l}\text { Fabricação de produtos de } \\
\text { metal }\end{array}$ & $4.840,3$ & 783,4 & 16,2 & $491.357,1$ & $909.212,8$ & 185,0 \\
\hline $\begin{array}{l}\text { Fabricação de máquinas e } \\
\text { equipamentos }\end{array}$ & $13.067,1$ & $2.208,5$ & 16,9 & $606.434,4$ & $456.722,6$ & 75,3 \\
\hline $\begin{array}{l}\text { Produtos de escritório e } \\
\text { informática }\end{array}$ & $34.741,8$ & $5.603,9$ & 16,1 & $955.954,5$ & $654.653,0$ & 68,5 \\
\hline $\begin{array}{l}\text { Fabricação de produtos } \\
\text { elétricos }\end{array}$ & $15.105,0$ & 725,9 & 4,8 & $528.732,7$ & $319.736,5$ & 60,5 \\
\hline $\begin{array}{l}\text { Fabricação de equipamentos } \\
\text { eletrônicos e de } \\
\text { comunicações }\end{array}$ & $78.988,0$ & $11.069,9$ & 14,0 & $810.046,9$ & $843.166,1$ & 104,1 \\
\hline Instrumentação & $31.027,8$ & 123,5 & 0,4 & $548.427,8$ & $139.949,2$ & 25,5 \\
\hline $\begin{array}{l}\text { Indústria automobilística } \\
\text { (exclui peças) }\end{array}$ & $41.783,3$ & $9.102,2$ & 21,8 & $1.019 .763,2$ & $679.893,6$ & 66,7 \\
\hline $\begin{array}{l}\text { - Fabricação de peças e } \\
\text { acessórios para veículos } \\
\text { automotores }\end{array}$ & $19.398,2$ & $3.274,6$ & 16,9 & $495.804,7$ & $387.385,1$ & 78,1 \\
\hline $\begin{array}{l}\text { Fabricação de produtos } \\
\text { diversos }\end{array}$ & $15.844,1$ & 209,4 & 1,3 & $640.683,2$ & $457.908,6$ & 71,5 \\
\hline Total & $40.759,6$ & $4.227,9$ & 10,4 & $726.486,3$ & $552.787,5$ & 76,1 \\
\hline
\end{tabular}

Fonte: IBGE/Projeto PIB para filiais brasileiras; European Commission para estatísticas mundiais. Elaboraçâo dos autores. 
TABELA 6

Relação de P\&D/vendas das 150 empresas multinacionais mais inovadoras do mundo com filiais brasileiras, segundo setores de atividade econômica

2006

\begin{tabular}{|c|c|c|c|}
\hline \multirow{2}{*}{ Setores de atividade econômica } & \multicolumn{2}{|c|}{$\begin{array}{c}\text { P\&D/vendas } \\
\text { (R\$) }\end{array}$} & \multirow{2}{*}{$\begin{array}{l}\text { Filiais } \\
\text { brasileiras/ } \\
\text { mundo }\end{array}$} \\
\hline & Mundo & $\begin{array}{l}\text { Filiais } \\
\text { brasileiras }\end{array}$ & \\
\hline Indústria extrativa & 1,1 & - & - \\
\hline Fabricação de produtos alimentícios & 2,0 & 0,3 & 13,2 \\
\hline Fabricação de produtos do fumo & 0,9 & 0,5 & 52,3 \\
\hline Fabricação de celulose e papel & 0,9 & 0,3 & 33,6 \\
\hline Fabricação de produtos químicos & 3,3 & 0,4 & 12,9 \\
\hline - Fabricação de produtos farmacêuticos & 15,1 & 1,3 & 8,8 \\
\hline Fabricação de artigos de borracha e plástico & 1,4 & 0,6 & 38,5 \\
\hline $\begin{array}{l}\text { Fabricação de produtos de minerais não } \\
\text { metálicos }\end{array}$ & 0,7 & 0,6 & 82,9 \\
\hline Metalurgia básica (metais ferrosos) & 2,5 & 0,7 & 29,6 \\
\hline Metalurgia de metais não-ferrosos & 0,7 & 0,0 & 2,4 \\
\hline Fabricação de produtos de metal & 1,0 & 0,1 & 8,7 \\
\hline Fabricação de máquinas e equipamentos & 2,2 & 0,5 & 22,4 \\
\hline Produtos de escritório e informática & 3,6 & 0,9 & 23,6 \\
\hline Fabricação de produtos elétricos & 2,9 & 0,2 & 7,9 \\
\hline $\begin{array}{l}\text { Fabricação de equipamentos eletrônicos e de } \\
\text { comunicações }\end{array}$ & 9,8 & 1,3 & 13,5 \\
\hline Instrumentação & 5,7 & 0,1 & 1,6 \\
\hline Indústria automobilística (exclui peças) & 4,1 & 1,3 & 32,7 \\
\hline $\begin{array}{l}\text { - Fabricação de peças e acessórios para } \\
\text { veículos automotores }\end{array}$ & 3,9 & 0,8 & 21,6 \\
\hline Fabricação de produtos diversos & 2,5 & 0,0 & 1,8 \\
\hline Total & 5,6 & 0,8 & 13,6 \\
\hline
\end{tabular}

Fonte: IBGE/Projeto PIB para filiais brasileiras; European Commission para estatísticas mundiais. Elaboração dos autores.

Estes indicadores traçam um perfil do comportamento das grandes empresas multinacionais mundiais no Brasil, sugerindo que o país, apesar de ser um mercado representativo de vendas, no que se refere às atividades de P\&D muito pouco é realizado localmente. 


\section{Testes estatísticos}

Os testes econométricos realizados têm por objetivo identificar a relevância da origem de capital nas atividades de P\&D da indústria brasileira. Para fazer tal avaliação, foram utilizados os modelos Tobit, quando a variável dependente assumir o valor da relação entre os gastos em $\mathrm{P} \& \mathrm{D} / \mathrm{v}$ endas, e Probit, quando esta assumir valor 1 ou 0 , relacionado à realização ou não de atividades de $\mathrm{P} \& \mathrm{D}$ pelas empresas brasileiras. ${ }^{15}$ Os modelos Tobit e Probit serão estimados em dados em cross-section para 2000, 2003 e 2005, separadamente. Para as grandes empresas presentes no estrato certo da Pintec, a estimaçáo foi realizada a partir de dados em painel não balanceado, ${ }^{16}$ e foram estimados somente por efeito aleatório, dado que a principal variável de interesse - origem de capital - é uma característica fixa ou quase fixa da empresa, perdendo significância na estimação em painel efeito fixo.

\subsection{Resultados}

A primeira questão que se buscou responder foi a importância da origem de capital na propensão das empresas a investir em P\&D. Este teste inicial teve por objetivo avaliar quais empresas - nacionais ou multinacionais - têm maior propensão a investir em P\&D no Brasil. ${ }^{17}$

A análise das estatísticas descritivas apresentada anteriormente sugeriu que empresas multinacionais realizam esforços mais elevados em P\&D. Todavia, este olhar inicial não considerou o porte e as características setoriais destas empresas, que podem estar mais propensas a realizar atividades de $\mathrm{P} \& \mathrm{D}$ não por serem multinacionais, mas sim empresas de grande porte ou por se concentrarem em setores cujas oportunidades tecnológicas ${ }^{18}$ são mais elevadas. Os testes realizados procuram isolar tais fatores, identificando a importância da origem de capital no esforço em P\&D.

A análise foi realizada inicialmente para grandes empresas (acima de 500 empregados), por meio dos testes Probit (probabilidade da empresa investir em

15 Para mais detalhes sobre os métodos utilizados, ver Cameron e Trivedi (2005).

16 Se um painel é formado por z unidades, em $n$ anos, ele é denominado painel balanceado se todas as $z$ unidades estão presentes em todos os $n$ anos da amostra. Se as unidades não estão presentes em todos os anos, trata-se de um painel desbalanceado.

17 Estudo similar foi realizado por Araujo (2005), cujo trabalho foi inspirador para este artigo.

18 Oportunidades tecnológicas referem-se à probabilidade de ocorrência de uma inovação, dado determinado esforço para que ocorra (ZUCOLOTO, 2004). 
$\mathrm{P} \& \mathrm{D})$ e Tobit (gastos em $\mathrm{P} \& \mathrm{D} /$ vendas), ambos em painel não balanceado, incluindo os anos 2000, 2003 e 2005.

Portanto, no modelo Tobit, a variável dependente, "ped_vend", representa os gastos em $\mathrm{P} \& \mathrm{D} / \mathrm{vendas}$ das empresas da amostra; no Probit, a variável dependente "esf_ped" assume valores 1 ou 0 se a empresa realizou ou não atividades de P\&D. No mais, a especificação dos modelos é similar, cujos regressores são: ${ }^{19}$

- D_EMNs - variável dummy, que assume valor um se a empresa é multinacional;

- $\quad$ In (pessoal ocupado) - logaritmo do pessoal ocupado (+);

- In (exportação) - logaritmo do valor exportado $(+)$;

- In (importação) - logaritmo do valor importado $(+)$

- part.mercado - participaçáo de mercado da empresa i, mensurada pela participaçáo de sua receita líquida de vendas na receita líquida de vendas do setor $(+)$;

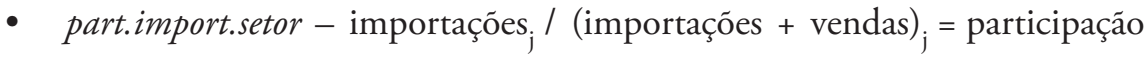
das importaçóes no setor $\mathbf{j}(-)$;

- D_cooperação - variável dummy que assume valor um se a empresa cooperou (+);

- D_outras.ativ.inov. - variável dummy que assume valor um se a empresa realizou outra atividade inovativa que náo $\mathrm{P} \& \mathrm{D}(+)$.

As variáveis independentes selecionadas têm por objetivo controlar as principais características das empresas. O pessoal ocupado é uma tradicional proxy do tamanho da empresa; variáveis de comércio exterior estão positivamente relacionadas à realização de atividades de $\mathrm{P} \& \mathrm{D}$, assim como outras atividades inovativas e a atuação tecnológica das empresas em cooperação com outras instituiçóes. A princípio, espera-se uma correlação negativa na participação das importaçôes no setor em que a empresa é classificada, uma vez que o suprimento por importados em determinada indústria pode estar relacionado à baixa competitividade e capacidade tecnológica de suas firmas.

Variáveis de controle setoriais (CNAE 2 dígitos) também foram incluídas em ambos os modelos.

Os resultados encontrados para a dummy de origem de capital foram negativos e estatisticamente significativos em ambos os casos. Portanto, empresas nacionais apresentaram maior probabilidade de investir em P\&D (Probit) e seu esforço em $\mathrm{P} \& \mathrm{D}$ (P\&D/vendas) é mais elevado (Tobit). ${ }^{20}$

19 Entre parênteses, os sinais esperados para as variáveis de controle.

20 Nos modelos realizados neste trabalho, deve-se observar o sinal do coeficiente de interesse, e não sua magnitude. 
TABELA 7

Testes realizados pelos modelos Probit e Tobit para grandes empresas (mais de 500 empregados)

\begin{tabular}{|c|c|c|}
\hline \multirow{3}{*}{ Regressores } & \multicolumn{2}{|c|}{$\begin{array}{c}\text { Coeficientes } \\
\text { (Desvio-Padrão) }\end{array}$} \\
\hline & Painel_Probit & Painel_Tobit \\
\hline & $\begin{array}{c}\text { Variável dependente: } \\
\text { esf_ped }\end{array}$ & $\begin{array}{c}\text { Variável dependente: } \\
\text { ped_vend }\end{array}$ \\
\hline \multirow[t]{2}{*}{ Intercepto } & $-4,2349 * * *$ & $-0,0298 * * *$ \\
\hline & $(0,5545)$ & $(0,0043)$ \\
\hline \multirow[t]{2}{*}{ D_EMNs } & $-0,2403 * *$ & $-0,0025^{\star * *}$ \\
\hline & $(0,1123)$ & $(0,0010)$ \\
\hline \multirow[t]{2}{*}{ log_pessoal ocupado } & $0,22176^{* * *}$ & 0,0004 \\
\hline & $(0,0751)$ & $(0,0006)$ \\
\hline \multirow[t]{2}{*}{ log_exportação } & 0,00728 & 0,0000 \\
\hline & $(0,0080)$ & $(0,0001)$ \\
\hline \multirow[t]{2}{*}{ log_importação } & $0,07575^{* * *}$ & $0,0003 * * *$ \\
\hline & $(0,0099)$ & $(0,0001)$ \\
\hline \multirow[t]{2}{*}{ part.mercado } & 1,5051 * & - \\
\hline & $(0,8448)$ & - \\
\hline \multirow[t]{2}{*}{ part.import.setor } & 0,04418 & $0,0687 * * *$ \\
\hline & $(2,0154)$ & $(0,0169)$ \\
\hline \multirow[t]{2}{*}{ D_cooperação } & $0,78857^{* * *}$ & $0,0060 * * *$ \\
\hline & $(0,0872)$ & $(0,0007)$ \\
\hline \multirow[t]{2}{*}{ D_outras.ativ.inov. } & $1,8579 * * *$ & $0,0153 * * *$ \\
\hline & $(0,1303)$ & $(0,0013)$ \\
\hline
\end{tabular}

*** significativo a $1 \% * *$ significativo a $5 \%$ * significativo a $10 \%$

O sinal dos coeficientes encontrados para as variáveis de controle estão de acordo com o esperado: há uma correlação positiva entre atividades de P\&D e tamanho das empresas, importaçôes, participação de mercado, realização de cooperação e de outras atividades inovativas. O resultado diferiu do esperado apenas no caso da participação das importaçóes por setor, em que se previa sinal negativo, e na ausência de significância na variável relacionada às exportaçóes. 
A seguir, o teste foi realizado considerando empresas de todos os portes ${ }^{21}$, separadamente para 2000, 2003 e 2005, utilizando modelo Tobit. ${ }^{22}$ Os resultados foram consistentes com os encontrados anteriormente: nos três anos, a dummy de origem de capital foi negativa e significativa. Portanto, empresas nacionais tendem a realizar maior esforço em $\mathrm{P} \& \mathrm{D}$ ( $\mathrm{P} \& \mathrm{D} /$ vendas) do que as multinacionais (Tabela 8).

TABELA 8

Testes realizados pelo modelo Tobit para empresas de todos os portes

\begin{tabular}{|c|c|c|c|}
\hline \multirow{3}{*}{ Regressores } & \multicolumn{3}{|c|}{$\begin{array}{c}\text { Tobit } \\
\text { Variável dependente: ped_vend }\end{array}$} \\
\hline & \multicolumn{3}{|c|}{$\begin{array}{l}\text { Coeficientes } \\
\text { (Desvio-Padrão) }\end{array}$} \\
\hline & 2000 & 2003 & 2005 \\
\hline \multirow[t]{2}{*}{ Intercepto } & $-0,0609 * \star *$ & $-0,1064^{* * *}$ & $-0,1366^{* * *}$ \\
\hline & $(0,0020)$ & $(0,0031)$ & $(0,0037)$ \\
\hline \multirow[t]{2}{*}{ D_EMNs } & $-0,0153 * * *$ & $-0,0212 * * *$ & $-0,0128 * * *$ \\
\hline & $(0,0016)$ & $(0,0025)$ & $(0,0026)$ \\
\hline \multirow[t]{2}{*}{ log_pessoal ocupado } & $0,0035^{* * *}$ & $0,0050 * * *$ & $0,0037 * * *$ \\
\hline & $(0,0004)$ & $(0,0006)$ & $(0,0007)$ \\
\hline \multirow[t]{2}{*}{ log_exportação } & $0,0003 * * *$ & $0,0016^{* * *}$ & $0,0003 * * *$ \\
\hline & $(0,0001)$ & $(0,0001)$ & $(0,0001)$ \\
\hline \multirow[t]{2}{*}{ log_importação } & $0,0003 * * *$ & $0,0006 * * *$ & $0,0010 * * *$ \\
\hline & $(0,0001)$ & $(0,0001)$ & $(0,0002)$ \\
\hline \multirow[t]{2}{*}{ part.mercado } & $-0,0519 * \star *$ & $-0,0919 * * *$ & $-0,0527$ ** \\
\hline & $(0,0166)$ & $(0,0232)$ & $(0,0229)$ \\
\hline \multirow[t]{2}{*}{ part.import.setor } & $0,0506 * * *$ & $-0,0627$ & $-0,1699 * * *$ \\
\hline & $(0,0173)$ & $(0,0366)$ & $(0,0381)$ \\
\hline \multirow[t]{2}{*}{ D_cooperação } & $0,0209 * * *$ & $0,0304^{* * \star}$ & $0,0464^{* * *}$ \\
\hline & $(0,0011)$ & $(0,0021)$ & $(0,0018)$ \\
\hline \multirow[t]{2}{*}{ D_outras.ativ.inov. } & $0,0166^{* * *}$ & $0,0130 * * *$ & $0,0380 * * *$ \\
\hline & $(0,0009)$ & $(0,0013)$ & $(0,0015)$ \\
\hline
\end{tabular}

*** significativo a $1 \%$ ** significativo a $5 \%$ * significativo a $10 \%$

21 Utilizando fator de expansão, apesar de suas limitações quanto à origem de capital.

22 Testes sem a utilização do fator de expansão também foram realizados, chegando a resultados similares. 
Ainda com o objetivo de avaliar a importância da origem de capital nos esforços de P\&D, o teste a seguir procura identificar quais empresas brasileiras - nacionais ou multinacionais - estão tecnologicamente mais próximas do benchmark internacional, cuja proxy são os esforços em P\&D - P\&D/vendas - setoriais da OCDE. ${ }^{23}$

TABELA 9

Testes

realizados pelo modelo Tobit com variável dependente alternativa

\begin{tabular}{l|c|c|c}
\hline \multirow{2}{*}{ Regressores } & \multicolumn{3}{|c}{ Variável dependente: pedi_ocde } \\
\cline { 2 - 4 } & \multicolumn{3}{c}{$\begin{array}{c}\text { Coeficientes } \\
\text { (Desvio-Padrão) }\end{array}$} \\
\cline { 2 - 4 } & 2000 & 2003 & 2005 \\
\hline Intercepto & $-8,879 * * *$ & $-1,7171 * * *$ & $-19567 * * *$ \\
& $(0,34099)$ & $(0,50197)$ & $(0,52628)$ \\
\hline D_EMNs & $-1,743 * * *$ & $-3,052 * * *$ & $-1,4971 * * *$ \\
& $(0,27320)$ & $(0,41228)$ & $(0,38676)$ \\
\hline log_pessoal ocupado & $0,4190^{* * *}$ & $0,8271 * * *$ & $0,6196 * * *$ \\
& $(0,06827)$ & $(0,09539)$ & $(0,09341)$ \\
\hline log_importação & $0,0751 * * *$ & $0,2257 * * *$ & $0,0830 * * *$ \\
& $(0,01438)$ & $(0,02254)$ & $(0,02183)$ \\
\hline part.import.setor & $0,0752 * * *$ & $0,1643 * * *$ & $0,13381 * * *$ \\
& $(0,01511)$ & $(0,02413)$ & $(0,02302)$ \\
\hline D_cooperação & $8,584 * * *$ & $-13,7345 * *$ & $-2,3637 * * *$ \\
& $(3,07858)$ & 6,22850 & $(5,72986)$ \\
\hline D_outras.ativ.inov. & $3,303 * * *$ & $4,5642 * * *$ & $5,7718 * * *$ \\
& $(0,18495)$ & $(0,35302)$ & $(0,26886)$ \\
\hline & $2,774 * * *$ & $2,3691 * * *$ & $5,4208 * * *$ \\
& $(0,16320)$ & $(0,22113)$ & $(0,22234)$ \\
\hline
\end{tabular}

*** significativo a $1 \% * *$ significativo a $5 \%$ * significativo a $10 \%$

Os indicadores da OCDE referem-se ao esforço tecnológico do grupo de empresas pertencentes a cada setor, e não somente das grandes empresas. Portanto, apesar das limitaçôes relacionadas ao fator de expansão, a comparação entre as empresas brasileiras e o benchmark internacional foi realizada considerando empresas brasileiras de todos os portes.

23 Por limitações na obtenção de informações, o esforço tecnológico da OCDE refere-se exclusivamente a 2000, enquanto o brasileiro refere-se a 2000, 2003 e 2005. 
O modelo inclui as variáveis independentes apresentadas anteriormente, enquanto a variável dependente assume a forma:

pedi_ocde $=\left(\mathrm{P} \& \mathrm{D} / \mathrm{vendas}_{\mathrm{ij}} /(\mathrm{P} \& \mathrm{D} / \text { vendas })_{\mathrm{OCDEj}}\right.$, que indica a distância entre $\mathrm{P} \& \mathrm{D} /$ vendas da empresa $\mathrm{i}$, setor $\mathrm{j}$, em relação ao esforço médio realizado pelo setor j nos países da OCDE.

Também neste caso, variáveis de controle setoriais (CNAE 2 dígitos) foram incluídas em ambos os modelos.

Para todos os anos analisados, foi encontrada uma relação negativa e significativa para a dummy de origem de capital; portanto, a distância entre os esforços em P\&D das empresas brasileiras e aqueles realizados pela OCDE é menor no caso das empresas nacionais, comparadas às multinacionais atuantes no Brasil.

Os testes realizados a seguir visam avaliar a relação existente entre o esforço de P\&D realizado pelas empresas nacionais e multinacionais. Relembrando Bas e Sierra (2002), os autores mencionaram que empresas multinacionais tendem a internacionalizar suas atividades tecnológicas para países desenvolvidos em áreas nas quais os países-sede e receptor dos investimentos possuem vantagens tecnológicas similares, com o objetivo de complementar suas capacitaçôes. Quando a internacionalização se direciona a países em desenvolvimento, as multinacionais tendem a atuar em áreas nas quais as empresas locais não possuem capacitaçôes significativas, com o objetivo de adaptar os produtos desenvolvidos na matriz para explorar os mercados locais. Na mesma linha, Patel (1996) observou que as subsidiárias tendem a ser tecnologicamente mais ativas em áreas nas quais os países hospedeiros são relativamente frágeis, não havendo coincidência entre os setores nos quais o país hospedeiro possui vantagem tecnológica e a presença significativa de empresas estrangeiras nos mesmos.

Na tentativa de identificar a existência destas relaçóes de complementaridade, é possível avaliar a afinidade entre os esforços tecnológicos de subsidiárias e empresas nacionais. Para tanto, o teste a seguir analisa a relação entre os esforços em P\&D de empresas nacionais e empresas multinacionais atuantes no mesmo setor (Tabela 10):

ped_vend_Nac $c_{i j}=\alpha_{i}+\beta 1$ ped_vend_EMN $\mathbf{j}+\beta 2 \ln$ (pessoal ocupado) ${ }_{i t}+$ $\beta 3 \ln$ (exportação) ${ }_{i t}+\beta 4 \ln \left(\right.$ importaçáo) ${ }_{i t}+\beta 5$ D_cooperaçáa ${ }_{i t}+\beta 6$ D_outras.ativ.inov. $+\mathbf{E}_{\mathrm{it}}$

Sendo:

Ped_vend_nac $\frac{\mathrm{ij}}{\mathrm{ij}}\left(\mathrm{P} \& \mathrm{D} / \mathrm{vendas}_{\mathrm{ij}}, \mathrm{i}=\mathrm{i}\right.$ empresa nacional;

Ped_vend_EMN_j: (P\&D/vendas) médio das empresas multinacionais no setor $j$. 
TABELA 10

Testes

realizados pelo modelo Tobit com variável dependente alternativa

\begin{tabular}{lr}
\hline \multicolumn{2}{c}{ Variável dependente: ped_vend_Nac } \\
\hline \multicolumn{2}{c}{$\begin{array}{c}\text { Coeficientes } \\
\text { (Desvio-Padrão) }\end{array}$} \\
\hline Intercepto & $-0,0202^{* * *}$ \\
\hline ped_vend_EMN.j & $(0,0059)$ \\
\hline log_pessoal ocupado & $\mathbf{0 , 1 4 4 9 * *}$ \\
& $\mathbf{( 0 , 0 6 9 6 )}$ \\
\hline log_exportação & $-0,0015^{*}$ \\
& $(0,0008)$ \\
\hline log_importação & 0,0000 \\
& $(0,0001)$ \\
\hline D_cooperação & $0,0007 * * *$ \\
& $(0,0001)$ \\
\hline D_outras.ativ.inov. & $0,0074 * * *$ \\
& $(0,0010)$ \\
\hline
\end{tabular}

*** significativo a $1 \% * *$ significativo a $5 \%$ * significativo a $10 \%$

Este resultado sugere uma correlação positiva entre os esforços setoriais em P\&D realizados por empresas nacionais e multinacionais no Brasil. Deste modo, independentemente de sua origem de capital, empresas brasileiras tendem a realizar mais $\mathrm{P} \& \mathrm{D} / \mathrm{vendas}$ em determinados setores. ${ }^{24}$ Este resultado contradiz os apresentados por Bas e Sierra (2002) e Pavitt (1996) para países em desenvolvimento, e merece ser mais bem avaliado em estudos posteriores. Todavia, é possível buscar explicaçóes para a correlaçâo entre as variáveis mencionadas no caso brasileiro. As possibilidades levantadas são as seguintes:

- o efeito de oportunidades tecnológicas setoriais predomina sobre origem de capital. Em setores intensivos em tecnologia, nos quais as oportunidades tecnológicas são maiores, empresas tendem a investir mais em $\mathrm{P} \& \mathrm{D}$, independentemente de sua origem de capital. Assim, em média, empresas das indústrias farmacêuticas e eletrônicas realizariam maior esforço em P\&D

24 Regressão similar foi realizada invertendo a origem de capital das variáveis independente e dependente de interesse, com resultados similares encontrados. Tais resultados sugerem a existência de correlação setorial nos esforços de P\&D/vendas de empresas nacionais e filiais, mas não possibilitam a identificação de causalidade. 
do que aquelas dos setores de madeira ou confecçóes, sendo nacionais ou multinacionais. As estatísticas descritivas da relação $\mathrm{P} \& \mathrm{D} /$ vendas setoriais por origem de capital corroboram tal hipótese;

- empresas nacionais e estrangeiras realizam P\&D em segmentos nos quais há oportunidades de mercado, que se apresentam como um desafio tecnológico. Tais oportunidades - no Brasil, as inovaçôes demandadas pelo pré-sal sáo o exemplo mais recente - exigem que as empresas realizem atividades de $\mathrm{P} \& D$, buscando inovar para ocupar posiçóes de mercado em aberto;

- empresas multinacionais realizam P\&D no Brasil visando, entre outros objetivos, complementar suas capacitaçóes. Para isto, estabelecem unidades de P\&D no país para acompanhar os desenvolvimentos tecnológicos realizados por empresas nacionais, ou estabelecer parcerias com estas. Entretanto, as estatísticas descritivas sugerem a baixa importância dos concorrentes no que se refere à cooperação, o que fragiliza a importância das parcerias entre empresas do mesmo setor.

- as empresas nacionais buscam imitar o comportamento de subsidiárias (efeito imitação), ou são pressionadas a aprimorarem suas capacitaçóes tecnológicas (efeito competição). Ressalva-se, entretanto, que alguns trabalhos cometem o equívoco de considerar, automaticamente, as correlaçóes apresentadas como efeito de transbordamento tecnológico de subsidiárias para empresas nacionais. Apesar de náo descartar esta possibilidade, o teste realizado náo é suficiente para confirmar esta hipótese, a qual poderá ser aperfeiçoada em trabalhos subsequentes, ao se inserirem, entre as variáveis explicativas, características de mercado - se concorrencial ou oligopolizado -, assim como o grau de concorrência entre empresas nacionais e estrangeiras.

Estas hipóteses necessitam ser analisadas em trabalhos posteriores. Até o momento, o que se conclui é a existência de correlação positiva e estatisticamente significativa entre esforços de P\&D de empresas nacionais e subsidiárias no Brasil, no mesmo setor.

\section{Conclusões}

Este trabalho discutiu o processo de internacionalização tecnológica, comparando as atividades de $\mathrm{P} \& \mathrm{D}$ de empresas multinacionais e nacionais na indústria brasileira.

Historicamente, a literatura mostra que este processo se iniciou como consequência da internacionalizaçáo produtiva impulsionada por empresas multinacionais: 
dada a necessidade de adaptarem produtos e processos às demandas dos países receptores de investimentos, tais empresas passavam a direcionar a estas localidades parte de suas atividades de P\&D. Mais recentemente, novos argumentos aparecem associados ao processo de internacionalização tecnológica, cujo fortalecimento foi possibilitado pelo advento das tecnologias de comunicação e informação, que facilitaram o processo de alocação de tarefas em escala global por meio de redes de informação intraempresariais. As empresas estariam realizando atividades de P\&D no exterior não somente para adaptar produtos e processos, mas também para reduzir os custos crescentes associados a estas atividades e monitorar os desenvolvimentos tecnológicos realizados em outros países.

Apesar destes argumentos, diversos trabalhos e estatísticas ainda demonstram que as atividades de P\&D continuam fortemente concentradas na matriz e, quando internacionalizadas, direcionam-se primordialmente para países desenvolvidos. A diferença observada nos últimos anos está relacionada à crescente participação das naçôes em desenvolvimento entre os investimentos em P\&D realizados por filiais de multinacionais. Como enfatizado por Reddy (2000), nas tecnologias desenvolvidas recentemente (como biotecnologia), é possível compartilhar as atividades de P\&D em módulos, que podem ser realizados em lugares diferentes, facilitando a divisão entre atividades centrais (core) e periféricas (no core). As atividades de P\&D periféricas foram, em parte, direcionadas para as filiais de nações em desenvolvimento, onde podem ser realizadas a custos menores, enquanto os investimentos centrais continuaram concentrados nos países-sede.

A literatura também discute se as empresas multinacionais internacionalizam suas atividades em $\mathrm{P} \& \mathrm{D}$ em áreas nas quais os países receptores possuem capacitaçôes tecnológicas relevantes ou, pelo contrário, em setores nos quais apresentam fragilidades, facilitando o domínio de mercado. Para Bas e Sierra (2002), o primeiro caso caracteriza a internacionalização para países desenvolvidos, enquanto o segundo predomina em naçóes em desenvolvimento. Associadamente, ganha espaço a literatura sobre transbordamentos tecnológicos, que avalia se as empresas domésticas se beneficiam da atuação de subsidiárias, ou se são limitadas (efeito crowding out) por elas. De modo geral, os estudos concluem que transbordamentos positivos predominam na relação de empresas com fornecedores e clientes (transbordamentos verticais), sendo menos frequentes entre concorrentes de um mesmo mercado relevante (transbordamentos horizontais).

A investigação empírica desta pesquisa observou o comportamento das empresas brasileiras em três ediçóes da Pintec. No caso brasileiro, a Pesquisa de Inovação 
Tecnológica (Pintec) identificou 1.410 empresas de grande porte, sendo 74,8\% nacionais e o restante, subsidiárias. As subsidiárias apresentaram participação no comércio exterior significativamente mais elevada do que as nacionais, no que se refere tanto a exportaçóes quanto importaçóes.

Os dados agregados sugeriram que as multinacionais apresentam indicadores de inovação superiores às nacionais em todos os critérios avaliados: percentual de empresas inovadoras; atividades internas de $\mathrm{P} \& \mathrm{D}$; aquisição de $\mathrm{P} \& \mathrm{D}$ e outros conhecimentos externos; aquisição de máquinas e equipamentos; e pessoal ocupado em P\&D. Mas, entre os investimentos em atividades inovativas, as empresas nacionais se destacam por direcionar proporcionalmente mais recursos à realização de P\&D. Antes de indicar elevado esforço tecnológico das empresas multinacionais no Brasil, diversos trabalhos ressaltam que esta proporção é, antes de tudo, reflexo do limitado investimento em P\&D das empresas nacionais (ARRUDA; VERMULM; HOLLANDA, 2006).

Entre as empresas inovadoras que cooperam, destaca-se a participação significativa da cooperaçáo entre fornecedores e clientes/consumidores, em detrimento de concorrentes. No caso das subsidiárias, também sobressai a cooperação com "outras empresas do grupo": considerando que filiais de multinacionais, especialmente de países em desenvolvimento, atuam na adaptação de produtos e processos ao mercado local, respondem por parcela da geraçấo de produtos desenvolvidos ao longo do globo e/ou utilizam grande parte de tecnologias geradas no exterior, a cooperação com a matriz torna-se, em todos os casos, de extrema relevância.

A significativa concentração de investimentos em $\mathrm{P} \& \mathrm{D}$ em grandes empresas é acompanhada por uma concentração similar em termos setoriais. No caso das subsidiárias, aproximadamente $50 \%$ da RLV concentra-se em três setores: indústria automobilística, máquinas e equipamentos e produtos químicos. Entre as nacionais, percentual similar é alcançado pela participação conjunta das indústrias de petróleo e álcool e de alimentos e bebidas. Em relaçáo aos investimentos em P\&D, esta concentração é ainda mais significativa. No caso das subsidiárias, a indústria automobilística representa 53,8\% dos esforços em P\&D. Em relação às empresas nacionais, petróleo e álcool e outros equipamentos de transporte respondem por 61,6\% deste montante.

O esforço tecnológico em $\mathrm{P} \& \mathrm{D}$, mensurado pela relação $\mathrm{P} \& \mathrm{D} /$ vendas, sugere que, se no agregado as empresas multinacionais apresentarem esforço mais elevado do que as nacionais, setorialmente este cenário sofre alteraçóes. Entre os 18 setores observados, em 12 o esforço realizado por empresas nacionais foi superior. Além 
disso, em $64 \%$ das indústrias, as empresas nacionais direcionam proporcionalmente mais recursos à realização de $\mathrm{P} \& \mathrm{D}$ em comparação às demais atividades inovativas.

Além das análises descritivas, foram adicionalmente realizados testes econométricos, com objetivo de avaliar tanto a probabilidade de as empresas realizarem $\mathrm{P} \& \mathrm{D}$ quanto seu gastos em $\mathrm{P} \& \mathrm{D} /$ vendas, por origem de capital, com base em modelos Probit e Tobit. Os resultados encontrados para a dummy de origem de capital foram negativos e estatisticamente significativos em ambos os casos. Portanto, empresas nacionais apresentaram maior probabilidade de investir em P\&D e seu esforço em $\mathrm{P} \& \mathrm{D}$ (P\&D/vendas) é mais elevado. Estes resultados foram confirmados quando se analisaram os esforços em $\mathrm{P} \& \mathrm{D} / \mathrm{vendas}$ de empresas brasileiras em relação àqueles realizados pelos países da $\mathrm{OCDE}$, considerados referência. Para todos os anos analisados, foi encontrada uma relaçáo negativa e significativa para a dummy de origem de capital; portanto, a distância entre os esforços em P\&D das empresas brasileiras e aqueles realizados na OCDE é menor no caso das empresas nacionais, comparadas às multinacionais atuantes no Brasil.

Por fim, o modelo final sugeriu uma correlação positiva entre os esforços setoriais em P\&D realizados por empresas nacionais e multinacionais no Brasil. Portanto, empresas brasileiras tendem a realizar mais $\mathrm{P} \& \mathrm{D} /$ vendas em determinados setores, em detrimento de outros. Este resultado contradiz os apresentados por Bas e Sierra (2002) e Pavitt (1996) para países em desenvolvimento, e merece ser mais bem avaliado em estudos posteriores.

\section{Referências bibliográficas}

AMSDEN, A. H.National firms leaders. The rise of the rest. New York: Oxford University Press, 2001, cap. 8.

AMSDEN, A. H.; HIKINO, T. Nationality of ownership in developing countries: who should "crowd out" whom in imperfect markets? In: IDE-JETRO CONFERENCE ON ECONOMIC DEVELOPMENT. Tokyo, 2006.

AMSDEN, A. H.; TSCHANG, T.; GOTO, A. Do foreign companies conduct R\&DD in developing countries? A new approach to analyzing the level of $\mathrm{R} \& \mathrm{D}$, with an analysis of Singapure. Asian Development Bank Institute, março 2001 (Working paper, 14).

ARAÚJO, R. D. Esforços tecnológicos das firmas transnacionais e domésticas. In: DE NEGRI, J. A.; SALERNO, M. S. (Orgs.). Inovaçôes, padrōes tecnológicos e desempenho das firmas industriais brasileiras. Rio de Janeiro: Ipea, 2005. 
ARCHIBUGI, D.; PIETROBELLI, C. The globalisation of technology and its implications for developing countries. Windows of opportunity or further burden? In: THE GLOBALISATION OF THE FINANCIAL MARKETS AND ITS EFFECTS ON THE EMERGING COUNTRIES. Seminário internacional organizado pelo Instituto Internacional Jacques Maritain e pela Cepal, 2002.

ARCHIBUGI, D.; MICHIE, J. Technological globalisation or national systems of innovation? Futures, v. 29, n. 2, p. 121-137, 1997.

ARRUDA, M.; VERMULM, R.; HOLLANDA, S. Inovação tecnológica no Brasil - a indústria em busca da competitividade local. Brasília: Associação Nacional de Pesquisa, Desenvolvimento e Engenharia das Empresas Inovadoras (Anpei), outubro 2006.

BACKER, K.; SLEUWAEGEN, L. Does foreign direct investment crowd out domestic entrepreneurship? Vlerick, 2002 (Working paper, 14).

BAS, C. L.; SIERRA, C. 'Location versus home country advantages' in R\&D activities: some further results on multinational's locational strategies. Research Policy, n. 31, p. 589-609, 2002.

BASKARAN, A.; MUCHIE, M. The impact of the national innovation systems on the flow and benefits of foreign direct investment to national economies. In: GLOBELICS. 2006. Disponível em: <http://www.globelicsacademy.net/2008/2008_lectures/GA2008\%20 Lecture\%2020b.pdf $>$.

BEA- Bureau of Economic Analysis. U.S. Department of Commerce. Estatísticas diversas. 2011.

BELL, M.; PAVITT, K. Technological accumulation and industrial growth: contrasts between developed and developing countries. Industrial and Corporate Change, v. 2, n. 2,1993.

BIAZI, E.; ALBUQUERQUE, E. M. Transnational corporations and patenting activities in Brazil: data description and statistical tests about the relative internalization of technological activities. Cedeplar-UFMG, agosto 2000.

BLOMSTRÖM, M.; KOKKO, A. The impact offoreign investment in host countries: a review of the empirical evidence. World Bank, 1996 (Policy research working paper, 1745).

CAMERON, A.; TRIVEDI, P. Microeconometrics using Stata. Stata Press Publication, 2009. CASSIOLATO, J. E.; LASTRES, H. M. M. Tecnoglobalismo e o papel dos esforços de P,D\&I de multinacionais no mundo e no Brasil. Parcerias Estratégicas, n. 20, junho 2005.

COSTA, I.; QUEIROZ, S. R. R. Foreign direct investment and technological capabilities in Brazilian industry. Research Policy, n. 31, p. 1431-1443, 2002. 
CORREAA, C. S. S. Os regimes de investimento direto estrangeiro no Brasil: regulação e política externa nacional. Dissertação (Mestrado) - Programa San Tiago Dantas, Convênio Unesp/ PUC-SP, 2007.

DOREMUS, P.; KELLER, W.; PAULY, L.; REICH, S. The myth of the global corporation. Princeton University Press, 1998.

DUNNING, J. (Towards an eclectic theory of international production: some empirical tests. Journal of International Business Studies, v. 11, p. 9-31, 1980.

FAJNZYLBER, F. Industrialização na América Latina: da "caixa-preta” ao "conjunto vazio". Cinqüenta anos de pensamento na Cepal. Textos selecionados. Chile: Cepal, 2000, p. 853-886.

GALINA, S. Desenvolvimento global de produtos: o papel das subsidiárias brasileiras de fornecedores de equipamentos do setor de telecomunicações. Tese (Doutorado) - Escola Politécnica/USP, 2003.

GAMMELTOFT, P. Internationalisation of R\&D: trends, drivers and managerial challenges. In: DRUID TENTH ANNIVERSARY SUMMER CONFERENCE ON DYNAMICS OF INDUSTRY AND INNOVATION: ORGANIZATIONS, NETWORKS AN SYSTEMS. Copenhagen, Dinamarca, 27-29 junho 2005.

GHOSH, J. The myth of foreign investment benefits. India Resource Center. 2002. Disponível em: <http:/www.indiaresource.org/issues/globalization/2003/themythofforeign.html>.

GONÇALVES, R. A empresa transnacional. In: KUPFER, D.; HASENCLEVER, L. (Orgs.). Economia industrial - fundamentos teóricos e práticas no Brasil. Rio de Janeiro: Editora Campus, 2002.

HADDAD, M.; HARRISON, A. Are there positive spillovers from direct foreign investment? Evidence from panel data for Morocco. Journal of Development Economics, n. 42, p. 51-74, 1993.

HIRATUKA, C. The role of transnational corporations in the Brazilian National System of Innovation. TD NEIT-IE-UNICAMP, v. 1, n. 3,2003.

HYMER, S. The international operation of national firms: a study of direct foreign investment , Cambridge, Mass: The MIT Press, 1960.

KONINGS, J. The effects of direct foreign investment on domestic firms: evidence from firm level panel data in emerging economies. Economics of Transition, v. 9, n. 3, p. 619-633, 2001. MEYER, K. E. Perspectives on multinational enterprises in emerging economies. Journal of International Business Studies, v. 35, n. 4, p. 259-276, julho 2004.

MININ, A. Patel and Pavitt revised: innovation and IP management in multinational corporations, 10 years after the case of "non-globalization". In: INTERNATIONAL 
WORKSHOP ONINNOVATION, MULTINATIONALSANDLOCALDEVELOPMENT. Catania, Italy, 30 de setembro a $1^{\circ}$ de outubro 2005.

OCDE. Internationalisation of industrial $R \& D$ : patterns and trends. 1998.

PATEL, P. Are large firms internationalizing the generation of technology? Some new evidence. IEEE Transactions of Engineering Management, v. 43, n. 1, fevereiro 1996.

PATEL, P.; PAVITT, K. National Systems of Innovation under Strain: the internationalisation of corporate R\&D. Science Policy Research Unit. University of Sussex, 1998 (SPRU Eletronic working papers series, n. 22). Disponível em: <http://www.sussex.ac.uk/spru/1-6-1-2-1.html>.

PAVITT, K. The multinational enterprise and the transfer of technology. In: DUNNING, J., The multinational enterprise. London, 1971, cap. 3..

PENROSE, E. The state and multinational enterprises in less-developed countries. In: Dunning, J. The multinational enterprise. London, 1971, cap. 8.

REDDY, P. Globalization of corporate R $\approx D$ - implications for innovation systems in host countries. New York: Routledge, 2000.

New trends in globalization of corporate R\&D and implications for innovation capability in host countries: a survey from India. World Development, v. 25, n. 11, p. 18211837, 1997.

ROJEC, J. Knowledge spillovers from foreign subsidiaries to domestic firms. Apresentação. Bucharest, 16 março 2007.

STREETEN, P. Costs and benefits of multinational enterprises in less-developed countries. In: DUNNING, J. The multinational enterprise. London, 1971, cap. 9..

UNCTAD. World investment report - Transnational corporations and the infrastructure change. Nova Iorque e Genebra: Organização das Nações Unidas, 2008.

- World investment report - Transnational corporations and the internationalization

of R\&D: capítulo IV (R\&D by TNCs and developing countries); capítulo V (Drivers and Determinants); capítulo VII (The role of national policies). Nova Iorque e Genebra: Organização das Nações Unidas, 2005.

VERNON, R. International investment and international trade in the product cycle. Quarterly Journal of Economics, v. 2, n. 60, p. 190-207, 1966.

VON ZEDTWITZ, M.; GASSMANN, O. Market versus technology drive in R\&D internationalization: four different patterns of managing research and development. Research Policy, n. 31, p. 569-588, 2002.

ZUCOLOTO, G. F. Inovação tecnológica na indústria brasileira: uma análise setorial. Dissertação (Mestrado) - Universidade de São Paulo, São Paulo, 2004. 
ZUCOLOTO, G. F.; CASSIOLATO, J. E. How globalized are R\&D activities: some evidence from BRICS countries. In: GLOBELICS-ÍNDIA. 2006. Disponível em: <http:// www.globelicsindia2006.org/Graziela\%20Ferrero\%20Zucoloto.pdf>.

ZUCOLOTO, G. F., TONETO JR., R. Esforço tecnológico da indústria de transformação brasileira: uma comparação com países selecionados. Revista de Economia Contemporânea, v. 9, n. 2, maio-agosto 2005 .

ENDEREÇOS PARA CORRESPONDENCIA:

Graziela Ferrero Zucoloto - graziela.fz@gmail.com Ipea - Instituto de Pesquisa Econômica Aplicada Av. Presidente Antônio Carlos, 51 - 10ªndar/sala 1012 20020-010 - Rio de Janeiro/ RJ

José Eduardo Cassiolato - cassio@ie.ifrj.br Instituto de Economia da UFRJ Avenida Pasteur, 250, salas 104 e 107, Urca 22290-240 - Rio de Janeiro/ RJ 